NOTICE: this is the author's version of a work that was accepted for publication in Drug and Alcohol Dependence. Changes resulting from the publishing process, such as peer review, editing, corrections, structural formatting, and other quality control mechanisms may not be reflected in this document. Changes may have been made to this work since it was submitted for publication. A definitive version was subsequently published in DRUG AND ALCOHOL DEPENDENCE [VOL. 129, ISSUE 3 (May 2013)] DOI: 10.1016/j.drugalcdep.2012.11.013. URL:

http://www.sciencedirect.com/science/article/pii/S0376871612004541

\title{
Tuberculosis, injecting drug use and integrated HIV-TB care: A review of the literature
}

\author{
Pippa Grenfell ${ }^{\mathrm{a}}$, Ricardo Baptista Leite ${ }^{\mathrm{b}}$, Richard Garfein ${ }^{\mathrm{c}}$, Smiljka de Lussigny ${ }^{\mathrm{b}}$, Lucy Platt ${ }^{\mathrm{a}}$, \\ Tim Rhodes ${ }^{\mathrm{a}}$ \\ ${ }^{a}$ Centre for Research on Drugs and Health Behaviour, London School of Hygiene \& Tropical Medicine, 15-17 Tavistock \\ Place, London WC1H 9SH, UK \\ ${ }^{\mathrm{b}}$ WHO-Europe Regional Office, Scherfigsvej 8, DK-2100 Copenhagen Ø, Denmark \\ ${ }^{c}$ Division of Global Public Health, School of Medicine, University of California San Diego, 9500 Gilman Drive, MC 0507, \\ La Jolla, CA 92093-0507, USA \\ Please address correspondence to: Pippa Grenfell, Centre for Research on Drugs and Health Behaviour, London School of \\ Hygiene and Tropical Medicine, 15-17 Tavistock Place, London WC1H 9SH, UK. Tel.: +44 207958 8266; fax: +44 20 \\ 7927 2701. E-mail address: pippa.grenfell@1shtm.ac.uk
}

\begin{abstract}
Background: People who inject drugs (PWID) are at increased risk of tuberculosis (TB) and reduced retention in treatment. There is a need to document strategies for integrated delivery of HIV, TB and drug dependency care.

Methods: This article reviews the literature on rates of TB mono- and co-infection, and published and grey literature descriptions of TB and HIV-TB care, among PWID.

Results: Latent TB infection prevalence was high and active disease more common among HIVpositive PWID. Data on multidrug-resistant TB and co-infections among PWID were scarce. Models of TB care fell into six categories: screening and prevention within HIV-risk studies; prevention at TB clinics; screening and prevention within needle-and-syringe-exchange (NSP) and drug treatment programmes; pharmacy-based TB treatment; TB service-led care with harm reduction/drug treatment programmes; and TB treatment within drug treatment programmes. Co-location with NSP and opioid substitution therapy (OST), combined with incentives, consistently improved screening and prevention uptake. Small-scale combined TB treatment and OST achieved good adherence in diverse settings. Successful interventions involved collaboration across services; a client-centred approach; and provision of social care. No peer-reviewed studies described models of integrated HIV-TB care for PWID but grey literature highlighted key components: co-located services, provision of drug treatment, multidisciplinary staff training; and remaining barriers: staffing inefficiencies, inadequate funding, police interference, and limited OST availability.
\end{abstract}

Conclusions: Integration with drug treatment improves PWID engagement in TB services but there is a need to document approaches to HIV-TB care, improve surveillance of TB and co-infections among PWID, and advocate for improved OST availability.

\section{Keywords:}

Injecting drug use, Tuberculosis, HIV, Opioid substitution therapy, Models of care, Integration 


\section{Introduction}

The burden of HIV and hepatitis C virus (HCV) among people who inject drugs (PWID) has been widely documented (Aceijas and Rhodes, 2007; Jones et al., 2010; Mathers et al., 2008; Palmateer et al., 2010) and evidence of harm reduction and HIV treatment interventions reviewed (Jones et al., 2010; Palmateer et al., 2010; Wolfe et al., 2010). Their tuberculosis (TB)-related healthcare needs, however, have received significantly less attention. PWID are at increased risk of TB for a number of reasons. Poverty, homelessness, overcrowding and imprisonment, harms to which drug users are vulnerable, are key social determinants of TB (Deiss et al., 2009; Galea and Vlahov, 2002; Lonnroth et al., 2009). Co-infection with HIV also greatly increases the risk of latent TB infection (LTBI) progressing to active disease (McShane, 2005). TB care typically involves repeated, regular contact with health services to which PWID may have poorer access and adherence (Deiss et al., 2009).

Screening for LTBI has traditionally involved tuberculin skin testing (TST), in which placement and reading of the test occurs 2-3 days apart. A chest X-ray is then used to exclude active TB and determine eligibility for isoniazid preventive therapy (IPT), recommended for people living with HIV (PLHIV) with LTBI but not active disease (World Health Organization, 2011b). Both IPT and active TB treatment involve taking multiple medications for at least 6 months, under direct observation in the case of treatment (DOTS; Menzies et al., 2007; World Health Organization, 2006). TB treatment is further complicated by prevalent co-infections, such as $\mathrm{HCV}$, and therapeutic interactions with opioid substitution therapy (OST) and anti-retroviral therapy ((ART) World Health Organization, 2007). Without appropriate drug dependency treatment, PWID suffer worse HIV and TB treatment outcomes than people who do not inject drugs (Cayla et al., 2009; Horsburgh et al., 2010; Lucas et al., 2002; Palepu et al., 2003). Incomplete TB treatment can lead to morbidity, mortality, drug resistance and continued transmission (Gandhi et al., 2010).

Effective strategies to deliver HIV, TB and drug dependency care in combination are urgently needed (Friedland, 2010; Getahun et al., 2012; Sylla et al., 2007). Integrated HIV and TB services are critical to timely diagnosis and treatment of LTBI (Ait-Khaled et al., 2009) and TB-related health outcomes in PLHIV (Havlir et al., 2008). Combined ART and OST have improved ART access, adherence and treatment outcomes among HIV and HIV-HCV co-infected PWID (Palepu et al., 2006;

Sambamoorthi et al., 2000). Integration in practice, however, faces significant structural challenges. In many settings, HIV, TB and drug dependency services are vertically organised, resourced and managed and multidisciplinary care is lacking (Getahun et al., 2012). An assumption among nonspecialists that substance use and TB are too complex to be managed concurrently (Gelmanova et al., 2007), and prolonged hospitalisation for TB treatment without concurrent drug dependency treatment, are particular impediments to integration of TB care (Sarang et al., 2011). Poor OST access threatens integration efforts more broadly, particularly in Eastern Europe and Central Asia (Open Society Institute, 2008), where HIV cases among PWID continue to rise (European Centre for Disease Prevention and Control/WHO-Europe, 2011) and MDR-TB rates are among the highest in the world (World Health Organization, 2011a). The World Health Organization (WHO) has produced specific guidelines on collaborative provision of HIV and TB services for people who use drugs (PWUD; World Health Organization, 2009) and prioritises identification of "the best delivery models for most at-risk populations" (World Health Organization, 2011c). This paper builds on a recent review of TB among people who use drugs (Deiss et al., 2009) but focuses specifically on PWID, a socially marginalised group with complex treatment needs. Specifically, we aimed to (1) describe the prevalence, incidence and risk factors for TB, MDR-TB, and HIVTB and HCV-HIV-TB co-infections among PWID and (2) identify models of TB and HIV-TB care for PWID. 


\section{Methods}

Between November 2010 and May 2011, we searched OVID Medline, OVID EMBASE, OVID Global Health, Social Science Citation Index, CINAHL and WHO regional databases, combining indexed and free-text search terms regarding tuberculosis and injecting drug use (Fig. 1). Reference lists of included articles and key review papers were checked to identify eligible studies missed by the automated searches. Additional relevant articles known to the authors were also reviewed. Conscious of the limited peer-reviewed literature documenting integrated HIV-TB care for PWID, we supplemented this review with 'grey' literature, searching WHO (2011d), Stop TB Partnership (2011), UNODC (2011), Open Society Foundations (2011) and Harm Reduction International (2011) webbased resources using the terms 'tuberculosis' and 'drug use.'

\subsection{Inclusion and exclusion criteria}

We reviewed studies published since 1995 in English, French, Portuguese, Russian and Spanish. We included: quantitative studies reporting prevalence, incidence or risk factors for TB, MDR-TB, HIVTB and HCV-HIV-TB co-infections among PWID, including where this could be calculated from raw data; and studies describing models of TB or HIV-TB care for PWID. We considered a 'person who injects drugs' to be an individual who had ever injected drugs for non-medical purposes and we used the WHO definition of latent and active TB (including pulmonary and extra-pulmonary disease; World Health Organization, 2008). TB and HIV-TB services were defined as governmental or nongovernmental health or community-based services providing testing, prevention, treatment or other care for TB or HIV and TB, either directly or by referral. Model of care studies were included if they described interventions which (a) specifically targeting PWID or (b) targeted a wider population but included a component specific to PWID, such as OST or a needle and syringe exchange programme (NSP). We included experimental and observational studies, as well as descriptions of interventions with no evaluative component.

We excluded commentaries and editorials; review papers containing no primary data; conference abstracts with no full text; individual case reports. Epidemiological studies were excluded if: data were not stratified by history of injecting drug use (IDU); the study design was inappropriate or insufficiently described; the stage of TB was not specified (latent/active); or the method of TB diagnosis was unclear or did not meet the WHO definition. Evaluations of treatment regimens which did not clearly describe a model of care were excluded.

\subsection{Article screening, mapping and review}

All returned articles were screened by title and abstract and, where necessary, the full text was reviewed. For included studies, data were extracted on: author, year, language and journal of publication; study setting, aim, duration, population and methods; analysis strategy; key findings, conclusions and limitations. For epidemiological studies, we extracted data on the definition(s), prevalence and incidence of, and factors associated with, latent and active TB, MDR-TB, and HIVTB and HCV-HIV-TB co-infections among PWID. For model of care studies, we recorded: descriptions of TB, HIV and drug dependency care; service uptake; treatment adherence/completion and associated health outcomes and measures of effect. 


\section{Findings}

Our searches identified 4287 articles, 4167 of which did not meet our inclusion criteria and 31 of which could not be accessed. A total of 87 peer-reviewed articles and two grey literature reports were included in this review.

\subsection{Epidemiology of TB among people who inject drugs}

\subsubsection{Latent TB infection}

Thirty-one studies reported results of LTBI screening, typically by tuberculin skin testing (TST), among PWID recruited from community settings, homeless shelters, NSPs and HIV, TB and drug treatment services (Table 1; Alvarez Rodriguez and Godoy Garcia, 1999; Brassard et al., 2004; Cabarcos Ortiz de Barron et al., 2000; Converse et al., 1997; Cheung et al., 2002; Daley et al., 1998; Duarte et al., 2011; Durante et al., 1998; Golub et al., 2008; Howard et al., 2002; Kimura et al., 1999; Lifson et al., 1997; Lorvick et al., 1999; Malotte et al., 1999, 1998; Manoff et al., 1996; Perlman et al., 2001; Portu et al., 2002; Riley et al., 2002; Robertson et al., 2004; Robles et al., 1998; Rusen et al., 1999; Ruutel et al., 2011; Sadaphal et al., 2001; Salomon et al., 2000; Sanchez et al., 2010, 1995; Sterling et al., 1998; Vitek et al., 2009). In Europe, TST-positivity ranged from $17 \%$ to $52 \%$, highest among PWID prisoners in Spain in the early 1990s and lowest among OST centre clients in Estonia in 2007. Prevalence was lower in North America (12-39\%), where disparities between cities are likely to reflect differing local TB epidemiology and targeted control efforts (Brassard et al., 2004; Converse et al., 1997; Golub et al., 2008; Kimura et al., 1999; Lifson et al., 1997; Lorvick et al., 1999; Manoff et al., 1996; Sadaphal et al., 2001; Sterling et al., 1998). TST-positivity was consistently lower among PLHIV likely due to anergic reactions, a reduced capacity to mount an immune response (Daley et al., 1998; Table 1). Studies using a novel diagnostic technique, the interferon-gamma-release assay (IGRA), typically resulted in higher positivity rates but with considerable variation across settings and recruitment methods: over $60 \%$ of community-recruited PWID in Mexico and the US were IGRApositive, while OST centre clients in Estonia had a positivity rate almost 10-fold lower (Table 2; Converse et al., 1997; Garfein et al., 2010, 2009; Kimura et al., 1999; Ruutel et al., 2011).

Common predictors of TST-positivity included male gender, increasing age, a longer history of injecting drug use (IDU), HIV-negative status and higher CD4 counts (Table 1). Structural factors associated with LTBI included longer history of and duration of imprisonment in Mexico and Spain, respectively, and limited affordability of food in the US (Tables 1 and 2). In studies examining risk factors for LTBI among all PLHIV (including but not limited to PWID), infection was frequently associated with former or current IDU and, in some cases, crack cocaine or alcohol use; other independent predictors included unemployment, non-white ethnicity and being born overseas (Tables 1 and 2).

\subsubsection{Active TB disease: prevalence, incidence and multi-drug resistance}

Studies describing active TB epidemiology among PWID, often as a sub-group of PLHIV, reported on four indicators: prevalence and incidence of active disease, the proportion of AIDS diagnoses attributed to TB, and the proportion of MDR-TB among PWID TB patients. Active TB prevalence ranged from $0.5 \%$ to $66 \%$ with wide variation across settings, study populations, case detection methods and TB definition, some studies including both pulmonary and extra-pulmonary disease (Table 3; Alavi, 2008; Caro-Murillo et al., 2007; Duarte et al., 2011; Gyarmathy et al., 2009; Liang et al., 2008; Mertz et al., 2008; Muga et al., 2007; O’Donnell et al., 1995; Sanchez-Portocarrero et al., 1996; Sanchez et al., 1995; Silveira et al., 2006; Solomon et al., 2008; Sterling et al., 1998;

Tansuphasawadikul et al., 1999; Yoong and Cheong, 1997). The highest prevalence occurred among 
PWID passively referred to a TB clinic in Portugal prior to an active screening intervention, and among hospitalised HIV-positive PWID in Thailand and Iran (Table 3). Meanwhile, just 3\% of PWID prisoners actively screened in Spain and $0.5 \%$ of cohort members in the US had active disease (Table 3). Use of an NSP, TST-positive and HIV-positive status, and low CD4 count predicted active TB among PWID in Hungary, Spain and India, respectively, while in Thailand, male gender and IDU were independently associated with active disease among PLHIV (Table 3).

TB incidence ranged from 0.8 to 92.5 cases per 1000 person-years (Table 4; Cabarcos Ortiz de Barron et al., 2000; Daley et al., 1998; Girardi et al., 2005; Golub et al., 2008; Graham et al., 1996; Jansa et al., 1998; Jones et al., 1998; Markowitz et al., 1997; Muga et al., 2007; Rubinstien et al., 1996; Scholten et al., 2003; van Asten et al., 2003). In Europe, rates were highest in Spain among PWID AIDS patients routinely screened for TB (Cabarcos Ortiz de Barron et al., 2000) and lowest among cohort members in Austria and the UK (van Asten et al., 2003). US studies reported lower but similarly varied incidence, again likely to reflect local differences in population TB rates and IPT provision. No or incomplete IPT predicted TB risk in San Francisco and New York, respectively, while in Baltimore, a history of prison was somewhat protective (Table 4). Incidence was consistently higher among PLHIV and variously associated with HIV status and duration, low CD4, high viral load and more recent initiation and shorter duration of ART (Table 4).

The proportion of TB-related AIDS diagnoses among PWID ranged from 5 to $48 \%$ (Table 5; Amill et al., 2004; Castilla et al., 1995, 1997; Cayla et al., 1995; Chariyalertsak et al., 2001; Godoy et al., 1998; Jones et al., 1996; Laguardia and Merchan-Hamann, 2003; Schwoebel et al., 1995; Triol et al., 1996; Vall Mayans et al., 1997), highest in Spain and Portugal, the most TB-affected countries in Western Europe, and lowest in the UK, Puerto Rico and mainland US, where population TB rates are considerably lower (World Health Organization, 2010). Common predictors of TB as an AIDSdefining illness were male gender and acquisition of HIV through IDU (versus other transmission routes). Country-specific predictors included age under 30 and a history of prison in Spain, and birth overseas in France and the US (Table 5), reflective of higher TB incidence among these populations.

The proportion of MDR-TB among PWID with active TB varied from below $1 \%$ to $68 \%$ (Table 6 ; Akksilp et al., 2009; Banerjee et al., 2008; Liang et al., 2008; Liu et al., 1998; Mdivani et al., 2008; Shamaei et al., 2009; Suarez-Garcia et al., 2009). Prevalence was highest in Georgia, where over half of all TB cases are MDR, and 10-fold lower in Spain and the US, where MDR-TB is far less common (World Health Organization, 2010). In Thailand and Georgia, a history of IDU predicted MDR-TB while in the US, IDU was less common among MDR than drug-susceptible TB cases, as was a history of incarceration or homelessness (Table 6). Other studies found no association between MDR-TB and IDU.

\subsubsection{HIV-TB and HCV-TB co-infections}

The prevalence of HIV-TB co-infection among PWID, reported in just four studies, varied similarly across settings. In the northwest of Spain, $20 \%$ of PWID inmates had positive results for both HIV and TST (Sanchez et al., 1995), while in Barcelona, 16\% and 29\% of incarcerated current and former injectors had concurrent HIV and active TB, the higher rate possibly reflecting older age and a longer history of IDU (Martin et al., 2000). Also in Catalonia, just 9\% of PWID enrolled in an NSP reported being HIV-positive and had latent or active TB (Alvarez Rodriguez and Godoy Garcia, 1999). In a smaller hospital-based study in Iran, just 1 of 31 (3\%) PWID was co-infected with HIV and active TB on admission (Sharifi-Mood and Metanat, 2006). No studies reported prevalence of HCV-TB or HCV-HIV-TB co-infections among PWID. 


\subsection{Models of TB care for PWID}

The majority of studies describing models of TB care for PWID were conducted in North America (n $=23$ ) with a small number of examples from Europe $(n=5)$ and Asia $(n=1)$ (Table 7; Batki et al., 2002; Chaisson et al., 2001; Dhingra et al., 2008; Duarte et al., 2011; FitzGerald et al., 1999; Golub et al., 2008; Gourevitch et al., 1999, 1996; Graham et al., 1996; Jansa et al., 1998; Juan et al., 2006; Lifson et al., 1997; Lorvick et al., 1999; Malotte et al., 2001, 1999, 1998; Marco et al., 1998; O'Connor et al., 1999; Paone et al., 1998; Perlman et al., 2003, 1997; Riley et al., 2002; Rusen et al., 1999; Ruutel et al., 2011; Salomon et al., 1999; Scholten et al., 2003; Smirnoff et al., 1998; Snyder et al., 1999; Swaminathan et al., 2007). These interventions can broadly be grouped into six categories (Fig. 2): (1) TB screening and prevention within PWID HIV risk studies; (2) TB prevention for PWID at TB clinics; (3) TB screening and prevention within NSP and drug treatment programmes, with referral for active disease screening; (4) pharmacy-based TB treatment with referral for drug treatment; (5) TB service-led screening, prevention and treatment in collaboration with harm reduction and drug treatment programmes; and (6) TB treatment within drug treatment programmes.

\subsubsection{TB screening and prevention within PWID HIV risk studies}

Eight studies described TB screening and/or prevention interventions nested within longitudinal PWID HIV risk studies, often offering financial and material incentives to encourage uptake (Table 7). Active disease screening and assessment of IPT eligibility were typically provided by referral to TB services, while co-located HIV prevention programmes offered HIV testing, education and CD4 monitoring (Fig. 2(1)).

Un-incentivised TB screening and prevention within the PWID 'ALIVE' cohort study in Baltimore, US, in which all cohort members were offered biannual TST and, where eligible, 6 months of selfadministered or directly observed IPT, resulted in relatively low TST uptake, IPT initiation and completion and had modest effects on TB incidence (Golub et al., 2008; Graham et al., 1996; Tables 8 and 10). Though early findings suggested declining incidence and a temporary elimination of TB (Graham et al., 1996), there was no significant difference in incidence prior to, during or after the intervention, likely due to low IPT uptake and completion (Golub et al., 2008).

In California, two randomised controlled trials (RCT) among PWID and crack users not in drug treatment showed monetary and non-monetary incentives to be extremely effective in achieving high rates of return for TST reading (Malotte et al., 1999, 1998; Table 8). A \$10 cash incentive was most effective, while equivalent-value food, travel and supermarket vouchers or a smaller cash amount had a significant but lesser impact (Malotte et al., 1998). Nurse-led motivational education, aiming to identify and overcome barriers to returning, had no additional effect.

A further two US studies described incentivised, 'two-step' TST, in which a booster test was offered 1-3 weeks after an initial negative result in order to maximise LTBI detection (Lifson et al., 1997; Swaminathan et al., 2007). Among PWID street-recruited in four US cities, return for TST reading was high for both initial and repeat tests (Table 8), increasing LTBI detection by $41 \%$ (Lifson et al., 1997). In New York, PWUD recruited from a methadone programme showed similar initial return rates but lower uptake of booster testing, increasing LTBI detection by just 14\% (Swaminathan et al., 2007). Though this approach increased screening coverage, not returning for booster-TST reading was independently associated with a history of IDU, homelessness and living in a shelter, and with HIVpositive status (Swaminathan et al., 2007).

In San Francisco, provision of incentivised, co-located TST, active disease screening and twiceweekly directly observed IPT (DOPT) achieved extremely high rates of TST uptake, IPT initiation, 
adherence and completion, and good rates of TST return and active disease screening (Lorvick et al., 1999; Tables 8 and 10). Participants received a $\$ 10$ cash incentive on return for TST reading, attendance for active disease screening and at each IPT visit. A subsequent RCT among PWID and crack users, also in California, found financial incentives to increase uptake of IPT delivered in studysite and community settings (Malotte et al., 2001). Participants were randomised to receive twiceweekly, fixed-site or outreach-delivered DOPT, all of the former and approximately half of the latter group receiving \$5 per visit. IPT completion was significantly higher among participants receiving incentives, whether fixed-site or outreach-delivered, while outreach alone resulted in very low adherence and completion (Table 10). Participant focus groups indicated that key reasons for stopping IPT included fear of side-effects and persistent survival- and drug-related concerns, while the authors argue that TB-related stigma may partially explain a preference for onsite rather than communitylocated treatment (Malotte et al., 2001).

\subsubsection{TB prevention for PWID at TB clinics}

Just one study described care for PWID via a TB service without links to NSP or drug treatment programmes (Chaisson et al., 2001; Fig. 2(2), Table 7). An RCT in Baltimore compared directly observed versus take-home IPT, with and without peer counselling, and immediate or deferred cash incentives. IPT-eligible PWID were randomised to receive: twice-weekly DOPT at the TB clinic; monthly take-home IPT with regular peer counselling; or routine care, with monthly take-home IPT and initial counselling by a TB nurse. Participants in each group were randomised to receive either an immediate or deferred monthly $\$ 10$ cash incentive. IPT completion did not differ between intervention groups but adherence was considerably higher among those receiving supervised rather than self-administered IPT (Table 10). Immediate rather than deferred cash incentives tended to improve adherence. Though self-reported adherence was better among the routine care versus peer counselling group, proxy indicators (electronic monitoring of pill bottles) indicated the reverse pattern and far lower adherence in both groups.

\subsubsection{TB screening and prevention within NSP and drug treatment programmes, with referral for active TB screening}

Eleven studies described provision of TB screening and/or prevention within services for PWID, including NSPs, OST centres, a methadone detoxification programme and a residential abstinencebased programme (Fig. 2(3), Table 7). All interventions provided onsite TST, HIV testing and respective harm reduction or drug treatment services according to the host programme, with referral to TB services for active disease screening. NSP and OST-centre models typically offered financial and material incentives to encourage return for TST reading.

\subsubsection{NSPs. In Baltimore, an NSP which promoted but did not actively offer TB screening to} clients, and provided travel tokens and a cash incentive on TST return, observed poor uptake but high return rates (Riley et al., 2002). Seeking TST was more common among female, frequent and lower intensity NSP clients and TST return more so among highly frequent service users (Table 8). A similar intervention in New York which actively offered TST to all NSP clients, with a \$10 cash incentive on TST return, achieved far higher uptake and return (Paone et al., 1998; Perlman et al., 1997). Clients who knew that HIV-related TB was curable were twice as likely to return (Salomon et al., 1999), while focus groups with clients and staff attributed the programme's success to: cooperation between TB and NSP staff; the view that TB screening fits within a harm reduction framework; popularity of NSP-located TB screening; the legal and fixed-site nature of the NSP; links to medical services; and the involvement of social work interns to avoid overburdening NSP staff (Paone et al., 1998). Incentivised TST at community-based NSPs in Canada showed similar effects on 
return rates, particularly where larger cash incentives were offered. Among NSP clients in Vancouver, all of whom were offered TST, return rates almost doubled after the introduction of $\$ 5$ (Can) cash incentives (FitzGerald et al., 1999; Table 8). In Toronto, TST uptake and return rates were extremely high among NSP clients offered $\$ 10$ cash for TST placement and $\$ 15$ on return, attributed both to participants' relationship with the NSP and financial incentivisation (Rusen et al., 1999). The authors advocate for similar provision of incentivised IPT via NSP and OST programmes (FitzGerald et al., 1999; Rusen et al., 1999).

3.2.3.2. Drug dependency treatment programmes. Six studies described TB prevention co-located with OST programmes in the US. From 1985, a methadone programme within a primary care centre in New York provided directly observed or take-home IPT for eligible clients (most opting for the former; Gourevitch et al., 1999, 1996). Early findings indicated high rates of IPT initiation, adherence and completion (Gourevitch et al., 1996), although, by 1996, just a third of eligible HIV-positive clients had initiated IPT and, of those, less than half had completed a 12-month course (Gourevitch et al., 1999; Table 10). TB incidence was markedly reduced among IPT completers, though the difference was of borderline significance only, and likely due to small sample sizes. Key reasons for IPT non-completion were leaving the methadone programme and experiences or concerns of hepatotoxicity. A second study across nine methadone programmes in New York, in which TSTpositive or anergic PWID were offered DOPT in conjunction with methadone, also reported relatively low rates of IPT initiation, adherence and completion (Scholten et al., 2003; Table 10). Over a third of clients refused IPT and, similarly, leaving methadone treatment and medical contraindication were common reasons for not initiating or completing therapy. TB incidence was significantly reduced among HIV-positive participants completing at least 6 months of IPT, and was independently predicted by shorter IPT duration, HIV-positivity and a positive (rather than anergic) TST result.

In San Francisco, an RCT among HIV-negative PWID recruited via a methadone detoxification programme compared three approaches to IPT delivery: combined daily DOPT and methadone, with and without substance use counselling; and routine TB care, providing monthly take-home IPT by referral to an onsite TB clinic but no OST (Batki et al., 2002). Participants receiving DOPT with methadone remained on IPT for an average of 3-4 months longer and were more likely to complete therapy than the routine care group (Table 10), almost half of whom did not collect their initial IPT supplies. Substance use counselling, however, had no additional effect and the most common reason for IPT non-completion was dropping out of methadone treatment. Shorter retention in IPT was associated with depression but not with current alcohol or cocaine use, desire to achieve abstinence, homelessness or gender. Though this study did not evaluate the individual effects of DOPT and methadone on retention, the findings clearly highlight the benefits of integrated OST and IPT over routine TB care.

Also in San Francisco, an OST centre providing combined DOPT and methadone in close collaboration with the city TB programme and community health workers achieved far higher DOPT completion (75\%), with discontinuation most commonly related to hepatotoxicity (Snyder et al., 1999). Comparing the number of incident TB cases with those among TST-positive individuals not receiving DOPT, the programme was estimated to have prevented $95 \%$ of expected TB cases over three years and predicted to avert $57 \%$ of TB-related deaths over 10 years. Effective collaboration between OST and TB programmes was achieved through cross-service agreements on administration and resources, employment of a project manager, placement of TB nurses at the OST centre and staff training across disciplines. Incentives and enablers included expedited access to TB clinic appointments, provision of transport and refreshments, and the involvement of community health workers to facilitate access to TB-related care and adherence follow-up. Staff encouraged clients to 
develop 'adherence plans', detailing places in which they could be located and, in instances of nonadherence, were contacted by staff or actively sought by community health workers.

An OST centre in Connecticut, US, combined OST and IPT by adding liquid isoniazid to daily methadone doses for IPT-eligible clients (O'Connor et al., 1999). Almost three-quarters of clients completed 6 months of IPT but, again, the most common reason for discontinuation was discharge from methadone treatment. No participants experienced IPT-related toxicity and the approach was well accepted, adding little to staff workload, reducing the burden on clients to remember to take multiple medications, and facilitating monitoring of take-home IPT adherence. However, the authors stress the need for strategies to sustain IPT adherence following discharge from OST, involving local health and support services, and for larger controlled studies of this approach's effectiveness.

Just one study described a TB intervention within an abstinence-based drug treatment programme. In Barcelona, clients of a 6-month inpatient 'therapeutic community' were offered TST and where eligible, onsite DOPT, with referral to a hospital-based TB service on discharge (Jansa et al., 1998). TB incidence was not associated with IPT adherence but was significantly higher among those completing less than 9 months of IPT $(\mathrm{OR}=4.3)$, though rates had wide and overlapping confidence intervals. Staff experienced difficulties following up patients after discharge, while hepatotoxicity was a key reason for IPT refusal or drop-out. Though this intervention did not offer OST, the authors highlight the key role of methadone and residential treatment programmes in providing DOPT to PWID.

\subsubsection{Active TB screening at TB clinics, by referral from NSPs and OST centres. Four studies} described uptake of active disease screening at TB clinics, by referral from NSP and OST centres (Table 7). Among NSP clients in Toronto, referral uptake at a hospital-based TB clinic was considerably lower than incentivised TST return at the NSP, likely due to the off-site, early morning nature of referral appointments and lack of additional financial incentivisation (Rusen et al., 1999; Tables 8 and 9). Uptake was far higher among OST centre clients in San Francisco receiving facilitated referral for active disease screening (Snyder et al., 1999; Table 9). Before referral, OST centre staff explained the benefits of TB screening and prevention and the TB services' procedures. Referred clients received transport and food, were accompanied by a community health worker to their first TB clinic appointment and fast-tracked by the TB clinic to reduce waiting times.

Among NSP clients in New York, monetary incentives significantly increased uptake of chest X-ray referral at off-site TB services (Perlman et al., 2003). Prior to the intervention, clients received travel tokens and help from social work interns accessing benefits if uninsured (Paone et al., 1998; Perlman et al., 1997). On introduction of cash incentives, referral adherence increased dramatically (Table 9) and the duration between referral and attendance declined from 11 to 2 days. Having health insurance and being unstably housed were associated with attending for an X-ray, though not within the desired 7-day period. In Johvi, Estonia, an RCT among OST centre clients showed facilitated referral to TB services to be highly effective (Ruutel et al., 2011). All clients were offered incentivised LBTI screening (TST and IGRA) and those with positive results were randomised to receive either active referral - whereby an OST centre nurse scheduled the TB clinic appointment, provided a reminder and organised transport - or passive referral, the client scheduling their own appointment. IGRApositive clients receiving an active, rather than passive, referral were almost four times more likely to attend TB services, after controlling for age, gender, education, employment status, IDU duration, history of prison, previous TB contacts and TST and HIV results (Table 9). The programme was costeffective, popular with clients and did not present any major recruitment or referral challenges for staff. 


\subsubsection{Pharmacy-based TB treatment for PWID, with referral for drug treatment}

Just one study described a pharmacy-based model of TB care for PWID, in Valencia, Spain, in which TB patients at high risk of non-adherence were referred to their nearest community pharmacy for directly observed treatment (DOTS; Juan et al., 2006; Fig. 2(4), Table 7). Trained pharmacists supervised DOTS, emphasised the importance of adherence, reminded patients of upcoming TB appointments and followed up non-attendance together with a hospital-based social worker, as well as facilitating access to OST, travel, food and housing assistance. Compared with a retrospective cohort of demographically similar patients receiving self-administered TB treatment, adherence was three times higher (66\% versus $22 \%$ ), highlighting the promise of this approach. However, the authors consider that further evidence of its effectiveness is needed and that increased coordination with OST programmes would facilitate treatment uptake and adherence among PWID.

\subsubsection{TB service-led screening, prevention and treatment, in collaboration with drug treatment and harm reduction services}

One study described a TB service-led model of care, in Northern Portugal, collaborating with drug treatment, harm reduction, housing and public health services to improve early detection and treatment of TB among PWID (Duarte et al., 2011; Fig. 2(5), Table 7). Prior to the intervention, referral to TB services typically occurred following diagnosis and on discharge from hospital. In 2003, screening protocols and treatment adherence strategies were standardised across services and staff were trained in TB screening and treatment supervision, counselling, negotiation and referral. Outreach and drug treatment services facilitated access to annual TB screening in the community or by referral to TB services, providing transport where needed. IPT was offered to eligible clients and all partners supervised DOTS in collaboration with TB services, while PWID TB clients were referred to drug treatment centres for OST, arranging co-located DOTS and OST if desired. Clients were involved in developing adherence strategies and were followed up by collaborating services in cases of non-adherence. TB services provided onsite HIV testing and all collaborating services' offered regular HIV, HBV and HCV screening, referring to a hospital-based clinic for test confirmation and care. Since the intervention, TB screening uptake has improved markedly (Table 8), and DOTS nonadherence and discontinuation have declined (from $48 \%$ to $24 \%$ and $35 \%$ to $10 \%$, respectively). However, IPT uptake and completion has decreased somewhat (Table 10), likely reflecting its nonmandatory provision during the intervention.

\subsubsection{TB treatment within drug dependency treatment programmes}

Four studies described DOTS co-located with drug treatment programmes in primary, secondary and prison-based care settings (Fig. 2(6), Table 7). At a primary care and substance use centre in New York, clients with culture-confirmed active disease were offered 6-12 months of DOTS (Gourevitch et al., 1996). Seven of 12 PWID completed DOTS (58\%) while a further three (25\%) remained on treatment, the main reason for non-completion being leaving the methadone programme. Threequarters of patients were considered adherent, receiving at least five DOTS doses per week in $80 \%$ of the study period. The authors attributed the programme's success to its integration with an existing methadone programme familiar to clients, obviating the need to attend potentially stigmatising TB services. A larger programme, also in New York, provided twice-weekly outpatient or home-based DOTS via a methadone programme based at a non-profit hospital, achieving relatively good adherence (85\%) and completion (66\%; 59/90), with a dropout rate of just 5\% (Smirnoff et al., 1998). Staff aimed to encourage adherence without judgement and adjusted methadone doses on an individual basis, to account for interaction with TB medication. 
In Barcelona, a small programme offering DOTS to 31 PWID prisoners via a methadone programme, in collaboration with the city TB programme, achieved extremely high adherence (95\%): $100 \%$ among those remaining in prison and 90\% among released inmates (Marco et al., 1998). On release, clients were referred to a public methadone centre, and received food, housing aid and access to a residential socio-sanitary centre, aimed at improving DOTS adherence. A TB programme nurse attended the prison weekly and followed-up released patients, facilitating access to financial and housing support. DOTS adherence was independently associated with continuous treatment (inside or outside of prison) and completion in the prison setting, but not with OST location. Collaboration across services, including prisons, drug treatment centres and the city TB control programme, and the concurrent provision of methadone, were seen as key reasons for the success of the intervention, while the provision of financial aid proved highly cost-effective relative to the averted costs of abandoned treatment.

In Delhi, India, a pilot NGO-run detoxification centre delivered outpatient DOTS to 60 PWUD together with free buprenorphine, substance use counselling, food supplements and DOTS adherence advice, in collaboration with the national TB control programme (Dhingra et al., 2008). The programme achieved high treatment completion ( $83 \%$ of clients completed 6 months of DOTS), but has had to close since transferring from NGO to governmental administration (Smart, 2010).

\subsection{Integrated HIV and TB care}

Few studies of TB interventions targeting PWID mentioned concurrent HIV service delivery and none fully described or evaluated an integrated model of care. Case studies from the 'grey' literature, however, offer two models of combined HIV-TB care for PWID: (1) referral of OST clients for HIV and TB testing and care in India and (2) co-located OST, HIV and TB care via combined care centres in Ukraine. These studies do not report on service uptake or treatment outcomes but highlight key components of and challenges to integration.

A brief report from India describes provision of OST via four formerly NGO-managed centres now run by governmental AIDS organisations, with referral for HIV and TB testing and care (Smart, 2010). HIV-negative clients were accompanied to the nearest HIV testing centre every three months and those requiring treatment to one of two ART sites (6-8 km away). Details of TB screening are not provided but culture confirmation required referral to a private laboratory. Provision of care was limited by a lack of funding for transport and referral to private laboratories, while scale-up and provision of OST has been limited by difficulties recruiting qualified staff.

In Ukraine, three centres provided integrated HIV, TB and drug dependency treatment for PWID (Curtis, 2010). In Kriviy Rig, a combined care centre within a narcology dispensary provides OST and weekly consultations with TB and AIDS specialists, though DOTS and ART are only available at off-site treatment centres. Staffed by narcologists, a psychologist, a social worker and a full-time case manager, the centre's multidisciplinary approach and provision of OST are seen to underpin its success, though it remains vulnerable to a shortage of narcologists and limited support for OST across the health system. A second centre at the Dnipropetrovsk City AIDS clinic provides on-site OST, HIV and TB care, including DOTS, with weekly consultations from a TB specialist and psychologist, and harm reduction services provided by a local NGO. However, the programme has experienced funding problems, interference from local police and tension with local health services over refusal to accept referral clients, and can only deliver OST onsite. A third centre co-located with a narcology dispensary in Simferopol formerly provided daily OST and weekly onsite consultations with an AIDS centre doctor and access to TB care at an adjacent clinic. The centre has now closed due to a lack of funding but has left a legacy of multidisciplinary working across services. These case studies 
highlight the following essential components of integrated care: provision of a package of services for HIV, TB, drug dependency and other health needs; multidisciplinary care with tailored case management; development of trust between staff and patients; a harm reduction approach across services; an appropriate, convenient location; and collaborative efforts across governmental and nongovernmental organisations. However, major barriers to integration included insufficient training across specialties; inefficient staffing; restrictive OST availability and prescription; police interference; lack of funding and often poor infrastructure (Curtis, 2010).

The key strengths and challenges of each model of TB and HIV-TB care for PWID are summarised in Table 11.

\section{Discussion}

This article reviews the epidemiology of and models of care for TB and HIV-TB among PWID. Consistent with studies among people who use but do not necessarily inject drugs (Deiss et al., 2009) prevalence of latent TB infection was high, particularly among older, male, longer-term injectors. Active disease, though highly variable, reached over $60 \%$ and was consistently higher among HIVpositive PWID, in some cases linked to a low CD4 count or shorter duration of ART. These findings stress the need for TB care targeting PWID and integration with HIV services.

Although injecting drug use has been widely linked to reduced access and adherence to treatment (Craig et al., 2007), this review indicates a number of factors which could improve engagement of PWID in TB care (Table 11). Co-location of TB screening, prevention and treatment with NSP and OST programmes, provision of incentives and concurrent social care, collaboration across health and social care services, and a flexible approach to the timing and location of service delivery are likely to be key to reducing identified barriers to uptake among PWID, including unstable housing, limited contact with harm reduction or health services, stigma attached to attending TB services and difficulty keeping appointments when in employment (Batki et al., 2002; Dhingra et al., 2008; Duarte et al., 2011; FitzGerald et al., 1999; Gourevitch et al., 1996; Marco et al., 1998; O’Connor et al., 1999; Paone et al., 1998; Perlman et al., 1997; Rusen et al., 1999; Smirnoff et al., 1998; Snyder et al., 1999) (Table 12).

Recent technical advances also show promise for improving screening and prevention uptake among PWID. WHO have simplified guidance on determining IPT eligibility in resource-stretched settings, replacing mandatory chest X-rays with a simple four-symptom algorithm to exclude active TB (World Health Organization, 2011b). Although IPT is most effective in PLHIV with a positive TST-result and is still recommended where feasible, this is no longer a requirement for initiating preventive therapy. With appropriate training of staff delivering or referring PWID for TB care, these new guidelines are likely to reduce barriers to screening and prevention uptake among PWID. Furthermore, the increasing use of IGRAs removes many of the challenges of TST, a labour-intensive process requiring two client visits 2-3 days apart, prone to missing results particularly among PWID (Menzies et al., 2007), plagued with problems of inter-rater reliability and false-positives among BCG-vaccinated populations. In 2005, the Centers for Disease Control and Prevention recommended the QuantiFERON TB Gold IGRA "be used in all circumstances in which the TST is currently used" (Centers for Disease Control and Prevention, 2003). IGRAs have considerable promise and excellent specificity but longitudinal studies are needed to define their predictive potential (Centers for Disease Control and Prevention, 2003; Menzies et al., 2007; Stout and Menzies, 2008).

Discontinuation of methadone as a key reason for not completing TB prevention or treatment highlights the need to tailor adherence strategies for PWID not in drug treatment, in conjunction with other health and social care services and with clients themselves (Getahun et al., 2012). Significant 
refusal and non-completion of IPT due to experienced or anticipated side-effects emphasises the urgency of identifying regimens with lower risk of hepatotoxicity (O'Connor et al., 1999). Drug-drug interactions, as well as additive side effects and toxicities, pose significant challenges to integration of HIV, TB and drug treatment, requiring a multidisciplinary approach to care and close monitoring across services (Altice et al., 2010; Getahun et al., 2012; Sylla et al., 2007). The growing availability of buprenorphine, as a form of OST which shows fewer interactions with HIV and TB treatment, may offer a viable alternative to facilitate integration (Friedland and Vlahov, 2011). Exploring PWIDs' views and experiences of TB care would also help to better inform TB awareness programmes targeting this population (Gourevitch et al., 1999; Scholten et al., 2003). Quantitative evidence linking TB-related knowledge to TST return (Salomon et al., 1999), and peer counselling to improved IPT adherence (Chaisson et al., 2001), suggest that peer education could be an effective way of engaging PWID in TB services. This approach has successfully reduced HIV-related risk behaviours (Broadhead et al., 1998) and increased ART adherence among this population (Broadhead et al., 2002).

The scarcity of data on MDR-TB and co-infections with HIV and HCV underlines the need for improved infectious disease surveillance among PWID. Multidrug-resistance poses a major threat to TB control, particularly in Eastern Europe and Central Asia. Modelling data from this region suggest that effective harm reduction could decrease HIV and TB mortality by $30 \%$ and $50 \%$, respectively, when combined with good MDR-TB control (Atun et al., 2005, 2007). Given the high prevalence of HCV among PWID and the risk of hepatotoxicity associated with TB prevention and treatment, incorporation of $\mathrm{HCV}$ care is also vital to improving the quality of integrated healthcare for PWID (Altice et al., 2010; Getahun et al., 2012).

This review highlights an important gap in the literature regarding integration of HIV, TB and drug dependency care, many successful but undocumented examples of which exist. Identifying approaches that can be applied and expanded in different health-system contexts is key. The experiences of combined care centres in Ukraine (Curtis, 2010) echo US providers' emphasis of the need for co-located TB and HIV services, provision of drug treatment, and multidisciplinary staff training (Sylla et al., 2007). However, a lack of training across specialties, inefficient staffing, inadequate funding and infrastructure, vertically structured health systems, police interference, and limited OST availability remain significant structural challenges to integration (Curtis, 2010; Friedland et al., 2007). In the Russian Federation, Turkmenistan and Uzbekistan, OST is prohibited (Latypov et al., 2012). While pilot OST programmes and their scale-up have begun in other parts of the region, availability remains restricted by the limited number of OST centres, high cost and user fees, long waiting lists, strict eligibility requirements, police harassment, unavailability of take-home doses and interrupted supplies (Open Society Institute, 2008). Improved OST and NSP availability is likely to be critical both to integration of care for PWID, and to wider efforts to curb HIV, TB and multidrug-resistance in this region.

The 'one-stop shop' approach, in which all services are provided in one dedicated care setting, is often hailed as the ideal model of integrated HIV-TB care and has shown potential among other populations (Uyei et al., 2011). However, its scale-up requires considerable resource, staff, administrative, infrastructural and political commitment which may not always be feasible or available. An alternative approach involves collaboration between multiple, existing health and social care services (Duarte et al., 2011; Gourevitch et al., 1996; Snyder et al., 1999), with facilitated and responsive referral mechanisms and arrangement of co-located treatment across healthcare and community settings (Duarte et al., 2011; Perlman et al., 2003; Ruutel et al., 2011; Snyder et al., 1999). This approach to integration is likely to be facilitated by establishing cross-service agreements on 
staff training, responsibilities and resource allocation; taking a multidisciplinary, client-centred approach to care; and involving local outreach services which work with PWID, particularly in settings where access to harm reduction and governmental health services is poor (Duarte et al., 2011; Open Society Institute, 2008). Ensuring continuity of care will also require good collaboration with prison health services (Getahun et al., 2012). Despite being associated with an increased risk of TB in some settings (Garfein et al., 2009; Sanchez et al., 1995) a history of imprisonment was protective against active disease and MDR-TB in two US studies (Banerjee et al., 2008; Golub et al., 2008), and a small but effective combined DOTS and OST programme among inmates in Spain (Marco et al., 1998) indicates the potential for effective TB care for PWID in prison settings. The scope for involvement of community pharmacies in TB treatment supervision, particularly those with colocated NSP or OST programmes, also warrants further attention (Juan et al., 2006).

Organizational challenges to integration, in relation to service planning and management, infrastructure, resource allocation and human resource capacity (Getahun et al., 2012; Tsiouris et al., 2007; Uwimana et al., 2012) will need to be addressed at the level of service delivery and national programming. Tackling existing stigma associated with HIV, TB and injecting drug use, and the possibility that PWID may experience additional discrimination when attending services initially dedicated to HIV or TB, will be key to improving access to integrated care for this population (Altice et al., 2010; Getahun et al., 2012; Sylla et al., 2007).

This review is subject to a number of limitations. We focus specifically on PWID as a population at high risk of TB with distinct healthcare needs. This is reflected in the search strategy used. We may, therefore, not have captured all literature documenting models of care which target people who use drugs but do not refer specifically to injecting drug use. However, this is counter-balanced by our inclusive eligibility criteria, incorporating interventions which target wider high-risk populations with a component specific to PWID, and by identifying additional studies manually. Our inclusion of 'grey' literature also allowed us to draw on emerging examples of integrated HIV-TB care from the field.

\subsection{Conclusion}

This review clearly illustrates the benefits of co-located, flexible, client-centred delivery of TB and drug dependency care and highlights emerging models of integrated HIV-TB care for PWID. There is, however, an urgent need to better document and evaluate approaches to HIV-TB care which, coupled with improved monitoring of TB and co-infections with HIV and HCV, will better inform service delivery for PWID. Integration of HIV, TB, HCV and drug dependency care requires political, financial and human resource commitment, appropriate attention to wider social care needs, and sustained advocacy for improved availability and scale-up of OST and harm reduction programmes. 


\section{Role of funding source}

The production of this document was carried out as part of a joint action with the Executive Agency for Health and Consumers entitled Scaling up access to high quality harm reduction treatment and care for injecting drug users in the European region (Harm Reduction) under Grant Agreement 20085202 Work Package 3: Integration of TB and HIV treatment services.

This document has been produced with the financial assistance of the European Union. The views expressed herein can in no way be taken to reflect the official opinion of the European Union.

The funder had no further role in the study design; collection, analysis and interpretation of data; in the writing of the report; or in the decision to submit the paper for publication.

\section{Contributors}

P.G., T.R. and L.P. designed the study and prepared the protocol; P.G. and R.B.L. conducted the literature searches and data extraction in discussion with T.R.; P.G. analysed and interpreted extracted data with input from all authors. All authors contributed to and have approved the final manuscript.

\section{Conflict of interest}

All authors declare that they have no conflicts of interest.

\section{Acknowledgements}

In addition to WHO-Europe and the European Union for steering and funding the project, respectively, we would like to thank Rachael Parker for administrative support and all members of the project advisory group. 


\section{References}

Aceijas, C. \& Rhodes, T., 2007. Global estimates of prevalence of HCV infection among injecting drug users. Int. J. Drug Policy 18, 352-358.

Ait-Khaled, N., Alarcon, E., Bissell, K., Boillot, F., Caminero, J.A., Chiang, C.Y., Clevenbergh, P., Dlodlo, R., Enarson, D.A., Enarson, P., Ferroussier, O., Fujiwara, P.I., Harries, A.D., Heldal, E., Hinderaker, S.G., Kim, S.J., Lienhardt, C., Rieder, H.L., Rusen, I.D., Trebucq, A., Van Deun, A., Wilson, N., 2009. Isoniazid preventive therapy for people living with HIV: public health challenges and implementation issues. Int. J. Tuberc. Lung. Dis. 13, 927-935.

Akksilp, S., Wattanaamornkiat, W., Kittikraisak, W., Nateniyom, S., Rienthong, S., Sirinak, C., Ngamlert, K., Mankatittham, W., Sattayawuthipong, W., Sumnapun, S., Yamada, N., Monkongdee, P., Anuwatnonthakate, A., Burapat, C., Wells, C.D., Tappero, J.W., Varma, J.K., 2009. Multi-drug resistant TB and HIV in Thailand: overlapping, but not independently associated risk factors. Southeast Asian J. Trop. Med. Public Health 40, 1264-1278 (Republished from Southeast Asian J. Trop. Med. Public Health 2009;40(September 5):1000-1014; PMID: 19842383).

Alavi, S.M., 2008. Relative frequency of infections among hospitalized injecting drug user - HIV positive patients in Razi hospital, Ahvaz, SW Iran (2001-2003). Jundishapur J. Microbiol. (JJM) 1, 6-9.

Altice, F.L., Kamarulzaman, A., Soriano, V.V., Schechter, M., Friedland, G.H., 2010. Treatment of medical, psychiatric, and substance-use comorbidities in people infected with HIV who use drugs. Lancet 376, 367-387.

Alvarez Rodriguez, M., Godoy Garcia, P., 1999. Prevalence of tuberculosis and HIV infections among participants in an intravenous drug user risk-control program. Rev. Esp. Salud Publ. 73, 375-381.

Amill, A., Gomez, M.d.l.A., Fernandez, D.M., Bangdiwala, S.I., Rios, E., Hunter, R.F., 2004. Changing profiles of injecting drug users with AIDS in a Hispanic population. Addiction 99, 1147-1156.

Atun, R.A., Lebcir, R., Drobniewski, F., Coker, R.J., 2005. Impact of an effective multidrug-resistant tuberculosis control programme in the setting of an immature HIV epidemic: system dynamics simulation model. Int. J. STD AIDS 16, 560-570.

Atun, R.A., Lebcir, R.M., McKee, M., Habicht, J., Coker, R.J., 2007. Impact of joined-up HIV harm reduction and multidrug resistant tuberculosis control programmes in Estonia: system dynamics simulation model. Health Policy 81, 207-217.

Banerjee, R., Allen, J., Westenhouse, J., Oh, P., Elms, W., Desmond, E., Nitta, A., Royce, S., Flood, J., 2008. Extensively drug-resistant tuberculosis in California, 1993-2006. Clin. Infect. Dis. 47, 450-457.

Batki, S.L., Gruber, V.A., Bradley, J.M., Bradley, M., Delucchi, K., 2002. A controlled trial of methadone treatment combined with directly observed isoniazid for tuberculosis prevention in injection drug users. Drug. Alcohol. Depend. 66, 283-293.

Brassard, P., Bruneau, J., Schwartzman, K., Senecal, M., Menzies, D., 2004. Yield of tuberculin screening among injection drug users. Int. J. Tuberc. Lung. Dis. 8, 988-993.

Broadhead, R.S., Heckathorn, D.D., Weakliem, D.L., Anthony, D.L., Madray, H., Mills, R.J., Hughes, J., 1998. Harnessing peer networks as an instrument for AIDS prevention: results from a peer-driven intervention. Public Health Rep. 113 (Suppl. 1), 42-57.

Broadhead, R.S., Heckathorn, D.D., Altice, F.L., van Hulst, Y., Carbone, M., Friedland, G.H., O'Connor, P.G., Selwyn, P.A., 2002. Increasing drug users' adherence to HIV treatment: results of a peer-driven intervention feasibility study. Soc. Sci. Med. 55, 235-246. 
Cabarcos Ortiz de Barron, A., Barrio Gomez, E., Lado Lado, F.L., Rodriguez Lopez, I., Lorenzo Zuniga, V., 2000. Correlation between mantoux and tuberculin's fraction from delayed hypersensitivity skin test, in a cohort from HIV-1 positive patients, in function of immunodeficiency level, and active tuberculosis incidence. Ann. Med. Intern. 17, 632-636.

Caro-Murillo, A.M., Castilla, J., Perez-Hoyos, S., Miro, J.M., Podzamczer, D., Rubio, R., Riera, M., Viciana, P., Lopez Aldeguer, J., Iribarren, J.A., de los SantosGil, I., Gomez-Sirvent, J.L., Berenguer, J., Gutierrez, F., Saumoy, M., Segura, F., Soriano, V., Pena, A., Pulido, F., Oteo, J.A., Leal, M., Casabona, J., del Amo, J., Moreno, S., Grupo de trabajo de la Cohorte de la Red de Investigacion en Sida, 2007. Spanish cohort of naive HIV-infected patients (CoRIS): rationale, organization and initial results. Enferm. Infecc. Microbiol. Clin. 25, $23-31$.

Castilla, J., Gutierrez-Rodriguez, A., Tello, O., 1995. Sociodemographic predictors and temporal trends of extrapulmonary tuberculosis as an AIDS-defining disease in Spain. AIDS 9, 383-388.

Castilla, J., Gutierrez, A., Guerra, L., Perez de la Paz, J., Noguer, I., Ruiz, C., Belza, M.J., Canon, J., 1997. Pulmonary and extrapulmonary tuberculosis at AIDS diagnosis in Spain: epidemiological differences and implications for control. AIDS 11, 1583-1588.

Cayla, J.A., Marco, A., Bedoya, A., Guerrero, R., Garcia, J., Martin, V., Jansa, J.M., De Olalla, P.G., Selwyn, P.A., 1995. Differential characteristics of AIDS patients with a history of imprisonment. Int. J. Epidemiol. 24, 1188-1196.

Cayla, J.A., Rodrigo, T., Ruiz-Manzano, J., Caminero, J.A., Vidal, R., Garcia, J.M., Blanquer, R., Casals, M., Working Group on Completion of Tuberculosis Treatment in Spain, 2009. Tuberculosis treatment adherence and fatality in Spain. Respir. Res. 10, 121.

Centers for Disease Control and Prevention, 2003. Guidelines for using the QuantiFERON(R)-TB test for diagnosing latent Mycobacterium tuberculosis infection. MMWR 52, 15-18.

Chaisson, R.E., Barnes, G.L., Hackman, J., Watkinson, L., Kimbrough Lpn, L., Metha, S., Cavalcante, S., Moore, R.D., 2001. A randomized, controlled trial of interventions to improve adherence to isoniazid therapy to prevent tuberculosis in injection drug users. Am. J. Med. 110, 610-615.

Chariyalertsak, S., Sirisanthana, T., Saengwonloey, O., Nelson, K.E., 2001. Clinical presentation and risk behaviors of patients with acquired immunodeficiency syndrome in Thailand, 1994-1998: regional variation and temporal trends. Clin. Infect. Dis. 32, 955-962.

Cheung, R.C., Hanson, A.K., Maganti, K., Keeffe, E.B., Matsui, S.M., 2002. Viral hepatitis and other infectious diseases in a homeless population. J. Clin. Gastroenterol. 34, 476-480.

Converse, P.J., Jones, S.L., Astemborski, J., Vlahov, D., Graham, N.M.H., 1997. Comparison of a tuberculin interferon-assay with the tuberculin skin test in high-risk adults: effect of human immunodeficiency virus infection. J. Infect. Dis. 176, 144-150.

Craig, G.M., Booth, H., Story, A., Hayward, A., Hall, J., Goodburn, A., Zumla, A., 2007. The impact of social factors on tuberculosis management. J. Adv. Nurs. 58, 418-424.

Curtis, M., 2010. Building Integrated Care Services for Injection Drug Users in Ukraine. World Health Organization, Geneva, Switzerland.

Daley, C.L., Hahn, J.A., Moss, A.R., Hopewell, P.C., Schecter, G.F., 1998. Incidence of tuberculosis in injection drug users in San Francisco: impact of anergy. Am. J. Respir. Crit. Care Med. 157, 19-22.

Deiss, R.G., Rodwell, T.C., Garfein, R.S., 2009. Tuberculosis and illicit drug use: review and update. Clin. Infect. Dis. 48, 72-82. 
Dhingra, V.K., Lall, D., Aggarwal, N., Vashist, R.P., 2008. DOTS in drug addicts with TB: Delhi experience. Indian J. Tuberc. 55, 122-126.

Duarte, R., Santos, A., Mota, M., Carvalho, A., Marques, A., Barros, H., 2011. Involving community partners in the management of tuberculosis among drug users. Public Health 125, 60-62.

Durante, A.J., Selwyn, P.A., O’Connor, P.G., 1998. Risk factors for and knowledge of Mycobacterium tuberculosis infection among drug users in substance abuse treatment. Addiction 93, 1393-1401.

European Centre for Disease Prevention and Control/WHO-Europe, 2011. HIV/AIDS Surveillance in Europe 2010. European Centre for Disease Prevention and Control, Stockholm, Sweden.

FitzGerald, J.M., Patrick, D.M., Strathdee, S., Rekart, M., Elwood, R.K., Schecter, M.T., Montaner, J., O'Shaughnessy, M., 1999. Use of incentives to increase compliance for TB screening in a population of intravenous drug users. Vancouver Injection Drug Use Study Group. Int. J. Tuberc. Lung. Dis. 3, $153-155$.

Friedland, G., 2010. Infectious disease comorbidities adversely affecting substance users with HIV: hepatitis C and tuberculosis. J. Acquir. Immune Defic. Syndr. 55 (Suppl. 1), S37-S42.

Friedland, G., Vlahov, D., 2011. Integration of buprenorphine for substance-abuse treatment by HIV care providers. J. Acquir. Immune Defic. Syndr. 56 (Suppl. 1), S1-S2.

Friedland, G., Harries, A., Coetzee, D., 2007. Implementation issues in tuberculosis/HIV program collaboration and integration: 3 case studies. J. Infect. Dis. 196 (Suppl. 1), S114-S123.

Galea, S., Vlahov, D., 2002. Social determinants and the health of drug users: socioeconomic status, homelessness, and incarceration. Public Health Rep. 117, S135-S145.

Gandhi, N.R., Nunn, P., Dheda, K., Schaaf, H.S., Zignol, M., van Soolingen, D., Jensen, P., Bayona, J., 2010. Multidrug-resistant and extensively drugresistant tuberculosis: a threat to global control of tuberculosis. Lancet $375,1830-1843$.

Garfein, R.S., Lozada, R., Liu, L., Laniado-Laborin, R., Rodwell, T.C., Deiss, R., Alvelais, J., Catanzaro, A., Chiles, P.G., Strathdee, S.A., 2009. High prevalence of latent tuberculosis infection among injection drug users in Tijuana, Mexico. Int. J. Tuberc. Lung Dis. 13, 626-632.

Garfein, R.S., Laniado-Laborin, R., Rodwell, T.C., Lozada, R., Deiss, R., Burgos, J.L., Cuevas-Mota, J., Cerecer, P., Moser, K., Volker, M.L., Strathdee, S.A., 2010. Latent tuberculosis among persons at risk for infection with HIV, Tijuana, Mexico. Emerg. Infect. Dis. 16, 757-763.

Gelmanova, I.Y., Keshavjee, S., Golubchikova, V.T., Berezina, V.I., Strelis, A.K., Yanova, G.V., Atwood, S., Murray, M., 2007. Barriers to successful tuberculosis treatment in Tomsk, Russian Federation: non-adherence, default and the acquisition of multidrug resistance. Bull. WHO 85, 703-711.

Getahun, H., Gunneberg, C., Sculier, D., Verster, A., Raviglione, M., 2012. Tuberculosis and HIV in people who inject drugs: evidence for action for tuberculosis, HIV, prison and harm reduction services. Curr. Opin. HIV AIDS 7, 345-353.

Girardi, E., Sabin, C.A., d’Arminio Monforte, A., Hogg, B., Phillips, A.N., Gill, M.J., Dabis, F., Reiss, P., Kirk, O., Bernasconi, E., Grabar, S., Justice, A., Staszewski, S., Fatkenheuer, G., Sterne, J.A.C., Antiretroviral Therapy Cohort Collaboration, 2005. Incidence of tuberculosis among HIV-infected patients receiving highly active antiretroviral therapy in Europe and North America. Clin. Infect. Dis. 41, 1772-1782.

Godoy, P., Castilla, J., Rullan, J.V., 1998. Incidence and risk factors of the association of AIDS and tuberculosis in Spain. Med. Clin. 110, 205-208. 
Golub, J.E., Astemborski, J., Ahmed, M., Cronin, W., Mehta, S.H., Kirk, G.D., Vlahov, D., Chaisson, R.E., 2008. Long-term effectiveness of diagnosing and treating latent tuberculosis infection in a cohort of HIVinfected and at-risk injection drug users. J. Acquir. Immune Defic. Syndr. 49, 532-537.

Gourevitch, M.N., Wasserman, W., Panero, M.S., Selwyn, P.A., 1996. Successful adherence to observed prophylaxis and treatment of tuberculosis among drug users in a methadone program. J. Addict. Dis. 15, 93104.

Gourevitch, M.N., Hartel, D., Selwyn, P.A., Schoenbaum, E.E., Klein, R.S., 1999. Effectiveness of isoniazid chemoprophylaxis for HIV-infected drug users at high risk for active tuberculosis. AIDS 13, 2069-2074.

Graham, N.M.H., Galai, N., Nelson, K.E., Astemborski, J., Bonds, M., Rizzo, R.T., Sheeley, L., Vlahov, D., 1996. Effect of isoniazid chemoprophylaxis on HIV-related mycobacterial disease. Arch. Intern. Med. 156, 889894.

Gyarmathy, V.A., Neaigus, A., Ujhelyi, E., 2009. Vulnerability to drug-related infections and co-infections among injecting drug users in Budapest, Hungary. Eur. J. Public Health 19, 260-265.

Harm Reduction International, 2011. Website: Reports Section. http://www.ihra.net/reports (accessed 31.05.11).

Havlir, D.V., Getahun, H., Sanne, I., Nunn, P., 2008. Opportunities and challenges for HIV care in overlapping HIV and TB epidemics. JAMA 300, 423-430.

Horsburgh Jr., C.R., Goldberg, S., Bethel, J., Chen, S., Colson, P.W., Hirsch-Moverman, Y., Hughes, S., Shrestha-Kuwahara, R., Sterling, T.R., Wall, K., Weinfurter, P., McAuley, J., Beison, J., Wilson, F., LeDoux, C., Flood, J., Sun, S., Ortega, H., Reves, R., Blumberg, H.M., Tapia, J., Wing, J., Jacobson, S., Endyke-Doran, C., Etkind, S., Sharnprapai, S., Sutherland, W.M., Guled, H., Grabau, J., Miranda, W., Royce, R., DukesHamilton, C., Sanchez, J.M., Haley, C., Chavez-Lindell, T., Graviss, E., Chatterjee, S., Griffith, D.E., Kimerling, M., Tamhane, A., Naus, M., Fitzgerald, M., Nakajima, M., Hershfield, E., Roche, B., Selvam, N., Weis, S., Munguia, G., Yan, J., Venegas, H.L., Brown, S., Jones, M., 2010. Latent TB infection treatment acceptance and completion in the United States and Canada. Chest 137, 401-409.

Howard, A.A., Klein, R.S., Schoenbaum, E.E., Gourevitch, M.N., 2002. Crack cocaine use and other risk factors for tuberculin positivity in drug users. Clin. Infect. Dis. 35, 1183-1190.

Jansa, J.M., Serrano, J., Cayla, J.A., Vidal, R., Ocana, I., Espanol, T., 1998. Influence of the human immunodeficiency virus in the incidence of tuberculosis in a cohort of intravenous drug users: effectiveness of anti-tuberculosis chemoprophylaxis. Int. J. Tuberc. Lung Dis. 2, 140-146.

Jones, J.L., Burwen, D.R., Fleming, P.L., Ward, J.W., 1996. Tuberculosis among AIDS patients in the United States, 1993. J. Acquir. Immune. Defic. Syndr. Hum. Retrovirol. 12, $293-297$.

Jones, J.L., Hanson, D.L., Dworkin, M.S., Kaplan, J.E., Ward, J.W., 1998. Trends in AIDSrelated opportunistic infections among men who have sex with men and among injecting drug users, 1991-1996. J. Infect. Dis. 178, $114-120$.

Jones, L., Pickering, L., Sumnall, H., McVeigh, J., Bellis, M.A., 2010. Optimal provision of needle and syringe programmes for injecting drug users: a systematic review. Int. J. Drug Policy 21, 335-342.

Juan, G., Lloret, T., Perez, C., Lopez, P., Navarro, R., Ramon, M., Cortijo, J., Morcillo, E.J., 2006. Directly observed treatment for tuberculosis in pharmacies compared with self-administered therapy in Spain. Int. J. Tuberc. Lung Dis. 10, 215-221.

Kimura, M., Converse, P.J., Astemborski, J., Rothel, J.S., Vlahov, D., Comstock, G.W., Graham, N.M.H., Chaisson, R.E., Bishai, W.R., 1999. Comparison between a whole blood interferon-gamma release assay and 
tuberculin skin testing for the detection of tuberculosis infection among patients at risk for tuberculosis exposure. J. Infect. Dis. 179, 1297-1300.

Laguardia, J., Merchan-Hamann, E., 2003. Risk factors for tuberculous disease in AIDS cases reported in Brazil, from 1980 to 2000. Rev. Esp. Salud Publ. 77, 553-565.

Latypov, A., Bidordinova, A., Khachatrian, A., 2012. Opioid Substitution Therapy in Eurasia: How to Increase the Access and Improve the Quality. http://www.idpc.net/sites/default/files/library/IDPC-briefing-paper OSTinEurasia.pdf (accessed 31.05.11).

Liang, S.H., Lo, Y.-C., Lin, H.-H., Chang, S.-Y., Chen, M.-Y., Hsieh, S.-M., Sheng, W.-H., Sun, H.-Y., Hung, C.-C., Chang, S.-C., 2008. Seroprevalence of viral hepatitis and infectious complications among human immunodeficiency virus-infected injection drug users at a referral hospital. J. Microbiol. Immunol. Infect. 41, 200-208.

Lifson, A.R., Grant, S.M., Lorvick, J., Pinto, F.D., He, H., Thompson, S., Keudell, E.G., Stark, M.J., Booth, R.E., Watters, J.K., 1997. Two-step tuberculin skin testing of injection drug users recruited from communitybased settings. Int. J. Tuberc. Lung Dis. 1, 128-134.

Liu, Z., Shilkret, K.L., Finelli, L., 1998. Epidemiology of drug-resistant tuberculosis in New Jersey from 1991 to 1995. Int. J. Epidemiol. 27, 121-126.

Lonnroth, K., Jaramillo, E., Williams, B.G., Dye, C., Raviglione, M., 2009. Drivers of tuberculosis epidemics: the role of risk factors and social determinants. Soc. Sci. Med. 68, 2240-2246.

Lorvick, J., Thompson, S., Edlin, B.R., Kral, A.H., Lifson, A.R., Watters, J.K., 1999. Incentives and accessibility: a pilot study to promote adherence to TB prophylaxis in a high-risk community. J. Urban Health $76,461-467$.

Lucas, G.M., Gebo, K.A., Chaisson, R.E., Moore, R.D., 2002. Longitudinal assessment of the effects of drug and alcohol abuse on HIV-1 treatment outcomes in an urban clinic. AIDS 16, 767-774.

Malotte, C.K., Rhodes, F., Mais, K.E., 1998. Tuberculosis screening and compliance with return for skin test reading among active drug users. Am. J. Public Health 88, 792-796.

Malotte, C.K., Hollingshead, J.R., Rhodes, F., 1999. Monetary versus nonmonetary incentives for TB skin test reading among drug users. Am. J. Prev. Med. 16, 182-188.

Malotte, C.K., Hollingshead, J.R., Larro, M., 2001. Incentives vs outreach workers for latent tuberculosis treatment in drug users. Am. J. Prev. Med. 20, 103-107.

Manoff, S.B., Farzadegan, H., Munoz, A., Astemborski, J.A., Vlahov, D., Rizzo, R.T., Solomon, L., Graham, N.M.H., 1996. The effect of latent Mycobacterium tuberculosis infection on human immunodeficiency virus (HIV) disease progression and HIV RNA load among injecting drug users. J. Infect. Dis. 174, 299-308.

Marco, A., Cayla, J.A., Serra, M., Pedro, R., Sanrama, C., Guerrero, R., Ribot, N., Study Group of Adherence to Tuberculosis Treatment of Prisoners, 1998. Predictors of adherence to tuberculosis treatment in a supervised therapy programme for prisoners before and after release. Eur. Respir. J. 12, 967-971.

Markowitz, N., Hansen, N.I., Hopewell, P.C., Glassroth, J., Kvale, P.A., Mangura, B.T., Wilcosky, T.C., Wallace, J.M., Rosen, M.J., Reichman, L.B., 1997. Incidence of tuberculosis in the United States among HIVinfected persons. The Pulmonary Complications of HIV Infection Study Group. Ann. Intern. Med. 126, 123132.

Martin, V., Cayla, J.A., Bolea, A., Castilla, J., 2000. Mycobacterium tuberculosis and human immunodeficiency virus co-infection in intravenous drug users on admission to prison. Int. J. Tuberc. Lung Dis. 4, 41-46. 
Mathers, B.M., Degenhardt, L., Phillips, B., Wiessing, L., Hickman, M., Strathdee, S.A., Wodak, A., Panda, S., Tyndall, M., Toufik, A., Mattick, R.P., 2008. Global epidemiology of injecting drug use and HIV among people who inject drugs: a systematic review. Lancet 372, 1733-1745.

McShane, H., 2005. Co-infection with HIV and TB: double trouble. Int. J. STD AIDS 16, 95-100, quiz 101.

Mdivani, N., Zangaladze, E., Volkova, N., Kourbatova, E., Jibuti, T., Shubladze, N., Kutateladze, T., Khechinashvili, G., del Rio, C., Salakaia, A., Blumberg, H.M., 2008. High prevalence of multidrug-resistant tuberculosis in Georgia. Int. J. Infect. Dis. 12, 635-644.

Menzies, D., Pai, M., Comstock, G., 2007. Meta-analysis: new tests for the diagnosis of latent tuberculosis infection: areas of uncertainty and recommendations for research. Ann. Intern. Med. 146, 340-354.

Mertz, D., Viktorin, N., Wolbers, M., Laifer, G., Leimenstoll, B., Fluckiger, U., Battegay, M., 2008. Appropriateness of antibiotic treatment in intravenous drug users, a retrospective analysis. BMC Infect. Dis., 8 .

Muga, R., Ferreros, I., Langohr, K., de Olalla, P.G., Del Romero, J., Quintana, M., Alastrue, I., Belda, J., Tor, J., Perez-Hoyos, S., Del Amo, J., Spanish Multicenter Study Group of Seroconverters, 2007. Changes in the incidence of tuberculosis in a cohort of HIVseroconverters before and after the introduction of HAART. AIDS 21, 2521-2527. O’Connor, P.G., Shi, J.M., Henry, S., Durante, A.J., Friedman, L., Selwyn, P.A., 1999. Tuberculosis chemoprophylaxis using a liquid isoniazid-methadone admixture for drug users in methadone maintenance. Addiction 94, 1071-1075.

O’Donnell, A.E., Selig, J., Aravamuthan, M., Richardson, M.S.A., 1995. Pulmonary complications associated with illicit drug use: an update. Chest 108, 460-463.

Open Society Foundations, 2011. Website: Resource Center Publications and Articles.

http://www.soros.org/resources/articles publications (accessed 31.05.11).

Open Society Institute, 2008. Barriers to Access: Medication-assisted Treatment and Injection-driven HIV Epidemics. International Harm Reduction Development Program, Open Society Institute, New York, USA.

Palepu, A., Tyndall, M., Yip, B., O’Shaughnessy, M.V., Hogg, R.S., Montaner, J.S., 2003. Impaired virologic response to highly active antiretroviral therapy associated with ongoing injection drug use. J. Acquire. Immune Defic. Syndr. 32, 522-526.

Palepu, A., Tyndall, M.W., Joy, R., Kerr, T., Wood, E., Press, N., Hogg, R.S., Montaner, J.S., 2006. Antiretroviral adherence and HIV treatment outcomes among HIV/HCV co-infected injection drug users: the role of methadone maintenance therapy. Drug Alcohol Depend. 84, 188-194.

Palmateer, N., Kimber, J., Hickman, M., Hutchinson, S., Rhodes, T., Goldberg, D., 2010. Evidence for the effectiveness of sterile injecting equipment provision in preventing hepatitis $\mathrm{C}$ and human immunodeficiency virus transmission among injecting drug users: a review of reviews. Addiction 105, 844-859.

Paone, D., Perlman, D.C., Perkins, M.P., Kochems, L.M., Salomon, N., Jarlais, D.C.D., 1998. Organizational issues in conducting tuberculosis screening at a syringe exchange program. J. Subst. Abuse Treat. 15, 229-234.

Perlman, D.C., Perkins, M.P., Solomon, N., Kochems, L., Jarlais, D.C.D., Paone, D., 1997. Tuberculosis screening at a syringe exchange program. Am. J. Public Health 87, 862-863.

Perlman, D.C., Gourevitch, M.N., Trinh, C., Salomon, N., Horn, L., Des Jarlais, D.C., 2001. Cost-effectiveness of tuberculosis screening and observed preventive therapy for active drug injectors at a syringe-exchange program. J. Urban Health 78, 550-567. 
Perlman, D.C., Friedmann, P., Horn, L., Nugent, A., Schoeb, V., Carey, J., Salomon, N., Des Jarlais, D.C., 2003. Impact of monetary incentives on adherence to referral for screening chest X-rays after syringe exchangebased tuberculin skin testing. J. Urban Health 80, 428-437.

Portu, J.J., Aldamiz-Etxebarria, M., Agud, J.M., Arevalo, J.M., Almaraz, M.J., Ayensa, C., 2002. Tuberculin skin testing in intravenous drug users: differences between HIV-seropositive and HIV-seronegative subjects. Addict. Biol. 7, 235-241.

Riley, E.D., Vlahov, D., Huettner, S., Beilenson, P., Bonds, M., Chaisson, R.E., 2002. Characteristics of injection drug users who utilize tuberculosis services at sites of the Baltimore City Needle Cxchange Program. J. Urban Health 79, 113-127.

Robertson, M.J., Clark, R.A., Charlebois, E.D., Tulsky, J., Long, H.L., Bangsberg, D.R., Moss, A.R., 2004. HIV seroprevalence among homeless and marginally housed adults in San Francisco. Am. J. Public Health 94, 12071217.

Robles, R.R., Marrero, C.A., Reyes, J.C., Colon, H.M., Matos, T.D., Finlinson, H.A., Munoz, A., Melendez, M., Sahai, H., 1998. Risk behaviors, HIV seropositivity, and tuberculosis infection in injecting drug users who operate shooting galleries in Puerto Rico. J. Acquir. Immune. Defic. Syndr. Hum. Retrovirol. 17, 477-483.

Rubinstien, E.M., Madden, G.M., Lyons, R.W., 1996. Active tuberculosis in HIVinfected injecting drug users from a low-rate tuberculosis area. J. Acquir. Immune. Defic. Syndr. Hum. Retrovirol. 11, 448-454.

Rusen, I.D., Yuan, L., Millson, M.E., 1999. Prevalence of Mycobacterium tuberculosis infection among injection drug users in Toronto. CMJ 160, 799-802.

Ruutel, K., Loit, H.M., Sepp, T., Kliiman, K., McNutt, L.A., Uuskula, A., 2011. Enhanced tuberculosis case detection among substitution treatment patients: a randomized controlled trial. BMC Res. Notes 4, 192.

Sadaphal, P., Astemborski, J., Graham, N.M., Sheely, L., Bonds, M., Madison, A., Vlahov, D., Thomas, D.L., Sterling, T.R., 2001. Isoniazid preventive therapy, hepatitis C virus infection, and hepatotoxicity among injection drug users infected with Mycobacterium tuberculosis. Clin. Infect. Dis. 33, 1687-1691.

Salomon, N., Perlman, D.C., Friedmann, P., Perkins, M.P., Ziluck, V., Jarlais, D.C., Paone, D., 1999.

Knowledge of tuberculosis among drug users. Relationship to return rates for tuberculosis screening at a syringe exchange. J. Subst. Abuse Treat. 16, 229-235.

Salomon, N., Perlman, D.C., Friedmann, P., Ziluck, V., Jarlais, D.C.d., 2000. Prevalence and risk factors for positive tuberculin skin tests among active drug users at a syringe exchange program. Int. J. Tuberc. Lung Dis. $4,47-54$.

Sambamoorthi, U., Warner, L.A., Crystal, S., Walkup, J., 2000. Drug abuse, methadone treatment, and health services use among injection drug users with AIDS. Drug Alcohol Depend. 60, 77-89.

Sanchez, V.M., Alvarez-Guisasola, F., Cayla, J.A., Alvarez, J.L., 1995. Predictive factors of Mycobacterium tuberculosis infection and pulmonary tuberculosis in prisoners. Int. J. Epidemiol. 24, 630-636.

Sanchez, F., Balague, M., de Olalla, P.G., Colomes, J.L.L., Martin, V., Guerrero, R., Marco, A., Cayla, J.A., 2010. Treatment of latent Mycobacterium tuberculosis infection in intravenous drug users co-infected with HIV. J. Infect. Prevent. 11, 12-18.

Sanchez-Portocarrero, J., Perez-Cecilia, E., Jimenez-Escrig, A., Martin-Rabadan, P., Roca, V., Yague, M.R., Romero-Vivas, J., Palau, E., Picazo, J.J., 1996. Tuberculous meningitis: clinical characteristics and comparison with cryptococcal meningitis in patients with human immunodeficiency virus infection. Arch. Neurol. 53, 671676. 
Sarang, A., Meylakhs, A., Maron, E., Ivanova, T., Torban, M., 2011. Delivery of Effective Tuberculosis Treatment to Drug Dependent HIV-positive Patients. http://en.rylkov-fond.org/blog/tbr/effective-tb-treatment/ (accessed 31.05.11).

Scholten, J.N., Driver, C.R., Munsiff, S.S., Kaye, K., Rubino, M.A., Gourevitch, M.N., Trim, C., Amofa, J., Seewald, R., Highley, E., Fujiwara, P.I., 2003. Effectiveness of isoniazid treatment for latent tuberculosis infection among human immunodeficiency virus (HIV)-infected and HIV-uninfected injection drug users in methadone programs. Clin. Infect. Dis. 37, 1686-1692.

Schwoebel, V., Delmas, M.C., Ancelle-Park, R.A., Brunet, J.B., Klein, J.P., Halbich, H., Stroobant, A., Declercq, E., Laporte, A., Pillonel, J., Koch, M., Schwartlander, B., Rezza, G., Zaccarelli, M., Coutinho, R., Bindels, P., Santos Ferreira, M.O., D’Avillez Paixao, M.T., Estermann, J., 1995. Factors associated with extrapulmonary tuberculosis as an AIDS-defining disease in Europe. Tuberc. Lung Dis. 76, 281-285.

Shamaei, M., Marjani, M., Baghaei, P., Chitsaz, E., Tabar, E.R., Abrishami, Z., Tabarsi, P., Mansouri, D., Masjedi, M.R., 2009. Drug abuse profile - patient delay, diagnosis delay and drug resistance pattern - among addict patients with tuberculosis. Int. J. STD AIDS 20, 320-323.

Sharifi-Mood, B., Metanat, M., 2006. Infection among hospitalized injection drug users. J. Med. Sci. 6, 686689.

Silveira, J.M., Sassi, R.A.M., de Oliveira Netto, I.C., Hetzel, J.L., 2006. Prevalence of and factors related to tuberculosis in seropositive human immunodeficiency virus patients at a reference center for treatment of human immunodeficiency virus in the southern region of the state of Rio Grande do Sul, Brazil. J. Bras. Pneumol. 32 , $48-55$.

Smart, T., 2010. HIV and TB in practice in India: integrating TB/HIV care and other essential health services into ‘targeted interventions' for drug users. HIV and AIDS Treat. Pract., 2-9.

Smirnoff, M., Goldberg, R., Indyk, L., Adler, J.J., 1998. Directly observed therapy in an inner city hospital. Int. J. Tuberc. Lung Dis. 2, 134-139.

Snyder, D.C., Paz, E.A., Mohle-Boetani, J.C., Fallstad, R., Black, R.L., Chin, D.P., 1999. Tuberculosis prevention in methadone maintenance clinics. Effectiveness and cost-effectiveness. Am. J. Respir. Crit. Care Med. 160, 178-185.

Solomon, S.S., Hawcroft, C.S., Narasimhan, P., Subbraman, R., Cecelia, A.J., Srikrisknan, A.K., Suresh Kumar, M., Solomon, S., Gallant, J.E., Celentano, D.D., 2008. Comorbidities among HIV-infected injection drug users in Chennai, India. Indian J. Med. Res. 127, 447-452.

Sterling, T.R., Moore, R.D., Graham, N.M., Astemborski, J., Vlahov, D., Chaisson, R.E., 1998. Mycobacterium tuberculosis infection and disease are not associated with protection against subsequent disseminated M. avium complex disease. AIDS 12, 1451-1457.

Stop TB Partnership, 2011. Website: Resources Section. http://www.stoptb.org/resources/publications/technical docs.asp (accessed 31.05.11).

Stout, J.E., Menzies, D., 2008. Predicting tuberculosis - does the IGRA tell the tale? Am. J. Respir. Crit. Care Med. 177, 1055-1057.

Suarez-Garcia, I., Rodriguez-Blanco, A., Vidal-Perez, J.L., Garcia-Viejo, M.A., JarasHernandez, M.J., Lopez, O., Noguerado-Asensio, A., 2009. Risk factors for multidrug-resistant tuberculosis in a tuberculosis unit in Madrid, Spain. Eur. J. Clin. Microbiol. Infect. Dis. 28, 325-330.

Swaminathan, S., Schoenbaum, E.E., Klein, R.S., Howard, A.A., Lo, Y.T., Gourevitch, M.N., 2007. Two-step tuberculin skin testing in drug users. J. Addict. Dis. 26, 71-79. 
Sylla, L., Bruce, R.D., Kamarulzaman, A., Altice, F.L., 2007. Integration and co-location of HIV/AIDS, tuberculosis and drug treatment services. Int. J. Drug Policy 18, 306-312.

Tansuphasawadikul, S., Amornkul, P.N., Tanchanpong, C., Limpakarnjanarat, K., Kaewkungwal, J., Likanonsakul, S., Eampokalap, B., Naiwatanakul, T., Kitayaporn, D., Young, N.L., Hu, D.J., Mastro, T.D., 1999. Clinical presentation of hospitalized adult patients with HIV infection and AIDS in Bangkok, Thailand. J. Acquir. Immune Defic. Syndr. 21, 326-332.

Triol, I., Schwoebel, V., Delmas, M.C., Pinget, R., Laporte, A., Brunet, J.B., 1996. Factors associated with tuberculosis at AIDS diagnosis in France. AIDS 10, 223-228.

Tsiouris, S.J., Gandhi, N.R., El-Sadr, W.M., Gerald, F., 2007. Tuberculosis and HIVneeded: a new paradigm for the control and management of linked epidemics. J. Int. AIDS Soc. 9, 62.

United Nations Office on Drugs and Crime, 2011. Website: Publications Section.

http://www.unodc.org/unodc/en/publications-by-date.html (accessed 31.05.11).

Uwimana, J., Jackson, D., Hausler, H., Zarowsky, C., 2012. Health system barriers to implementation of collaborative TB and HIV activities including prevention of mother to child transmission in South Africa. Trop. Med. Int. Health 17, 658-665.

Uyei, J., Coetzee, D., Macinko, J., Guttmacher, S., 2011. Integrated delivery of HIV and tuberculosis services in sub-Saharan Africa: a systematic review. Lancet Infect. Dis. 11, 855-867.

Vall Mayans, M., Maguire, A., Miret, M., Alcaide, J., Parron, I., Casabona, J., 1997. The spread of AIDS and the re-emergence of tuberculosis in Catalonia, Spain. AIDS 11, 499-505.

van Asten, L., Langendam, M., Zangerle, R., Hernandez Aguado, I., Boufassa, F., Schiffer, V., Brettle, R.P., Robertson, J.R., Fontanet, A., Coutinho, R.A., Prins, M., 2003. Tuberculosis risk varies with the duration of HIV infection: a prospective study of European drug users with known date of HIV seroconversion. AIDS 17, 1201-1208.

Vitek, E., Gusseinova, N., Laricheva, N., Vasiliev, S., Molotilov, V., Sofronova, R., Kazionny, B., Cegielski, P., Nguyen, M.L., Nelson, L., Agerton, T., Wells, C., 2009. Factors associated with positive tuberculin skin test results among HIV-infected persons in Orel Oblast, Russia. Int. J. Tuberc. Lung Dis. 13, 829-835.

Watters, J.K., Biernacki, P., 1989. Targeted sampling - options for the study of hidden populations. Soc. Probl. $36,416-430$.

Wolfe, D., Carneri, M.P., Shepard, D., 2010. Treatment and care for injecting drug users with HIV infection: a review of barriers and ways forward. Lancet 376, 355-366.

World Health Organization, 2006. Treatment of Tuberculosis: Guidelines. World Health Organization, Geneva, Switzerland.

World Health Organization, 2007. 4. Management of Tuberculosis and HIV Coinfection: Clinical Protocol for the European Region. World Health Organization, Geneva, Switzerland.

World Health Organization, 2008. Global Tuberculosis Control: Surveillance, Planning, Financing. World Health Organization, Geneva, Switzerland.

World Health Organization, 2009. Policy Guidelines for Collaborative TB and HIV Services for Injecting and Other Drug Users: an Integrated Approach. Evidence For Action Technical Papers. World Health Organization, Geneva, Switzerland. 
World Health Organization, 2010. Global Tuberculosis Control 2010. World Health Organization, Geneva, Switzerland.

World Health Organization, 2011a. Global Tuberculosis Control Report 2011. World Health Organization, Geneva, Switzerland.

World Health Organization, 2011b. Guidelines for Intensified Tuberculosis Casefinding and Isoniazid Preventive Therapy for People Living with HIV in Resourceconstrained Settings. World Health Organization, Geneva, Switzerland.

World Health Organization, 2011c. Priorities in Operational Research to Improve Tuberculosis Care and Control. World Health Organization, Geneva, Switzerland. World Health Organization, 2011d. Website: Publications on Tuberculosis Section. http://www.stoptb.org/resources/publications/technical docs.asp (accessed 31.05.11).

Yoong, K.Y., Cheong, I., 1997. A study of Malaysian drug addicts with human immunodeficiency virus infection. Int. J. STD AIDS 8, 118-123. 


\section{Tables and Figures}

\section{Figure 1: Literature review search strategy}

1 IDU* OR (inject* adj3 drug*) OR (intravenous adj3 drug*) OR heroin OR addict* OR opiate* OR narco* OR (drug depend\#n*) OR (recreation* adj3 drug*) OR (harm reduction) OR syringe* OR methadone OR opioid* OR (syringe* adj3 shar*) OR (needle* adj3 shar*) OR (illegal* adj3 drug*) OR (illicit* adj3 drug*) ${ }^{1}$

2 Substance Abuse, Intravenous/ OR Needle Sharing/ OR Heroin Dependence/ OR Substance-Related Disorders/

3 \#1 OR \#2

4 TB OR tuberculo*

5 Tuberculosis/

6 \#4 OR \#5

7 \#3 AND \#6

For databases which do not use the 'adj3' function (which detects the occurrence of specified terms within three words of each other), terms were replaced with appropriate permutations e.g. 'shar* syringe*' OR 'syringe* shar*'.

Figure 2: Six models of TB care for PWID

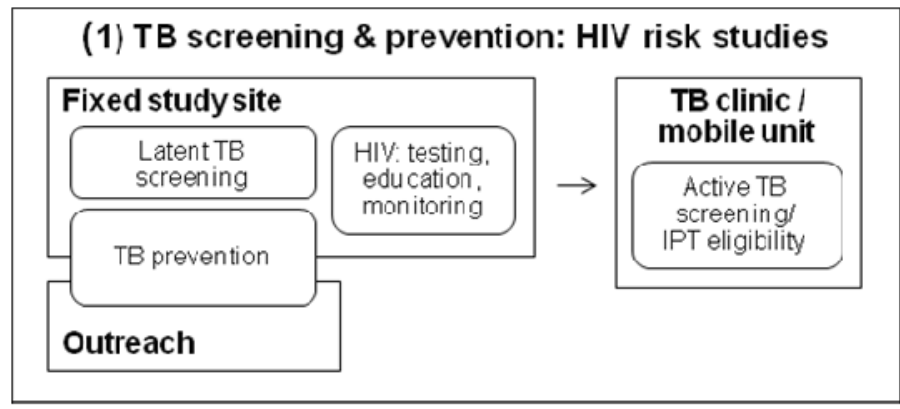

(3) TB screening \& prevention in NSP/drug treatment programmes, referral for active TB screening

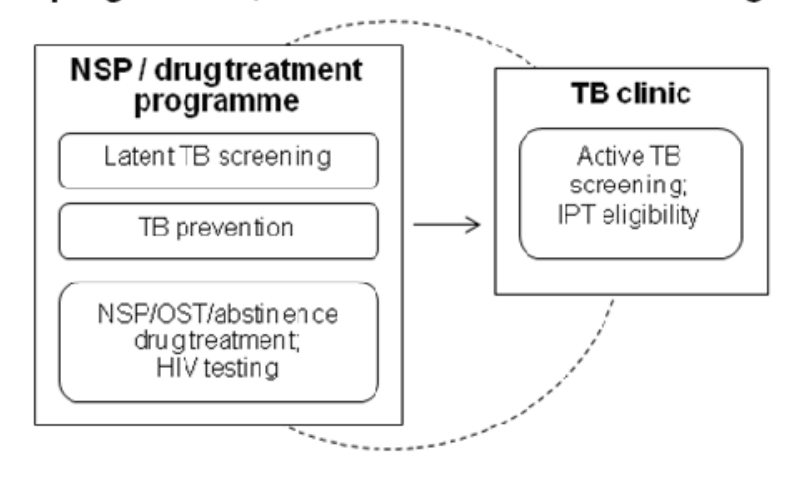

(5) TB service-led screening, prevention \& treatment: with drug treatment \& harm reduction programmes

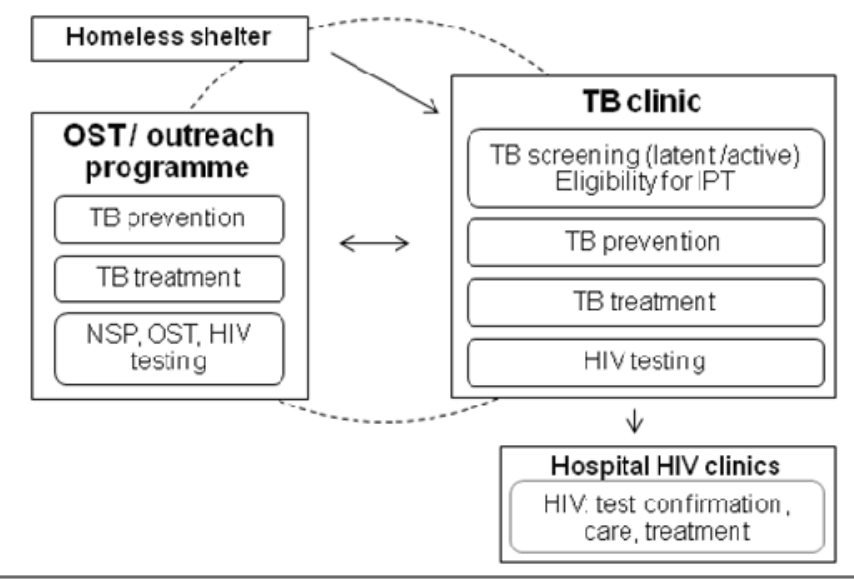

(2) TB prevention at TB clinics

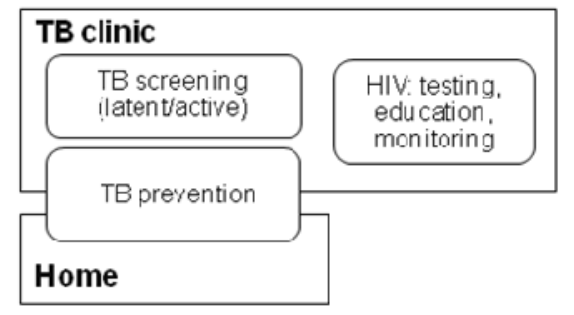

(4) Pharmacy-based TB treatment, referral for drug treatment

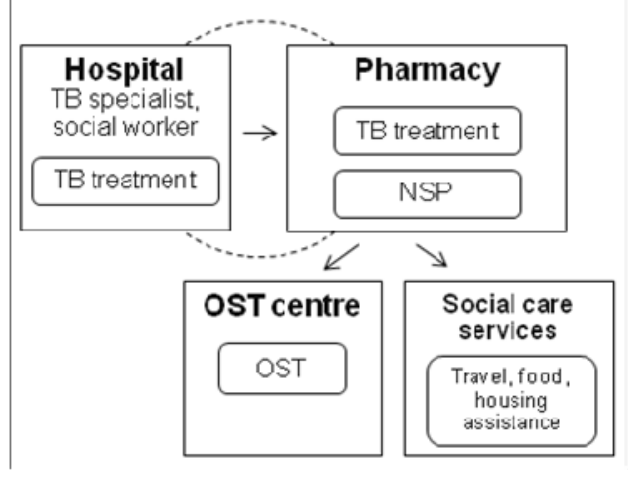

(6) TB treatment within drug treatment programmes

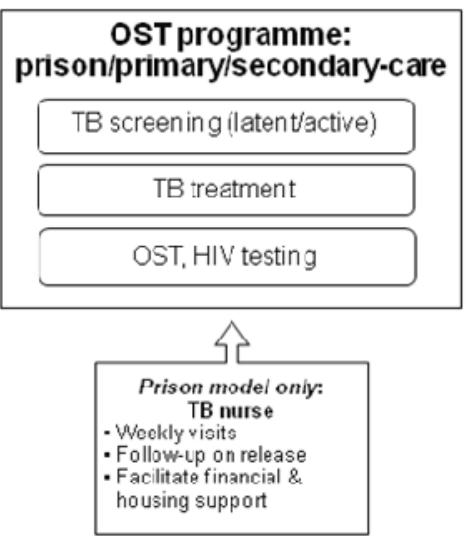

Black arrows indicate referral channels and dotted lines represent collaboration across services. 
Table 1: TST positivity among PWID

\begin{tabular}{|c|c|c|c|c|c|c|c|c|}
\hline \multirow[t]{2}{*}{ Author } & \multirow[t]{2}{*}{ Location } & \multirow[t]{2}{*}{ Study population } & \multirow[t]{2}{*}{ Recruitment } & \multirow{2}{*}{$\begin{array}{l}\text { No. } \\
\text { PWID } \\
\text { tested }\end{array}$} & \multirow{2}{*}{$\begin{array}{c}\text { TST-positivity } \\
\text { criteria } \\
\text { (induration size) } \\
\end{array}$} & \multicolumn{2}{|c|}{ TST-positivity } & \multirow[t]{2}{*}{ Predictive factors } \\
\hline & & & & & & All & HIV+ & \\
\hline \multicolumn{9}{|l|}{ Europe } \\
\hline Duarte (2011) & $\begin{array}{l}\text { Vila Nova de Gaia, } \\
\text { Portugal }\end{array}$ & $\begin{array}{l}\text { Ever-PWID attending TB } \\
\text { clinic for TST or treatment }\end{array}$ & $\begin{array}{l}\text { Review of clinic records (referred for } \\
\text { TST by NSP/OST programme) }\end{array}$ & 465 & $\geq 5-10 \mathrm{~mm}^{\mathrm{b}}$ & $21 \%$ & - & - \\
\hline Ruutel (2011) & Johvi, Estonia & PWID enrolled in OST & All clients approached & 112 & $\geq 5 \mathrm{~mm}$ & $17 \%$ & - & - \\
\hline Sanchez (2010) & Barcelona, Spain & $\begin{array}{l}\text { HIV+ PWID inmates \& } \\
\text { HIV-clinic clients }\end{array}$ & $\begin{array}{l}\text { Screened during assessment of } \\
\text { eligibility for IPT trial }\end{array}$ & 1110 & $\geq 5-10 \mathrm{~mm}^{\mathrm{b}}$ & - & $39 \%$ & - \\
\hline Vitek (2009) & Orel Oblast, Russia & $\begin{array}{l}\text { HIV+ PWID, AIDS-centre } \\
\text { clients }\end{array}$ & $\begin{array}{l}\text { Clients attending follow-up } \\
\text { appointments invited }\end{array}$ & 91 & $\geq 5 \mathrm{~mm}$ & - & $32 \%$ & $\mathrm{CD} 4 \geq 500$ \\
\hline Portu (2002) & $\begin{array}{l}\text { Basque region, } \\
\text { Spain }\end{array}$ & $\begin{array}{l}\text { PWID clients: therapeutic } \\
\text { community, OST centre, } 3^{\circ} \\
\text { care hospital }\end{array}$ & All clients invited & 1131 & $\geq 5 \mathrm{~mm}$ & $42 \%$ & $35 \%$ & HIV-negative \\
\hline $\begin{array}{l}\text { Cabarcos Ortiz } \\
(2000)\end{array}$ & $\begin{array}{l}\text { Santiago de } \\
\text { Compostela, Spain }\end{array}$ & $\begin{array}{l}\text { HIV+ PWID attending } \\
\text { hospital AIDS unit }\end{array}$ & All HIV+ clients screened for TB & 165 & $\geq 2 \mathrm{~mm}$ & - & $42 \%$ & - \\
\hline $\begin{array}{l}\text { Alvarez- } \\
\text { Rodriguez (1999) }\end{array}$ & Lleida, Spain & PWID NSP clients & Newly enrolled clients invited & 45 & $\begin{array}{l}\geq 5 \mathrm{~mm} \text { no } \mathrm{BCG} \\
\geq 15 \text { with } \mathrm{BCG}\end{array}$ & $27 \%$ & - & None \\
\hline Sanchez (1995) & Leon, Spain & Ever-PWID prisoners & All inmates invited & 445 & $>5 \mathrm{~mm}$ & $52 \%$ & - & $\begin{array}{l}\text { Older age, male, longer in prison, HIV- } \\
\text { negative }^{c}\end{array}$ \\
\hline \multicolumn{9}{|l|}{ North America } \\
\hline Golub (2008) & Baltimore, US & PWID, 'ALIVE' cohort ${ }^{d}$ & TST on enrolment, then biannually & 1753 & $\geq 5-10 \mathrm{~mm}^{\mathrm{b}}$ & $31 \%$ & $16 \%$ & $H I V+: \mathrm{CD} 4<200, \mathrm{BMI}<21$ \\
\hline Brassard (2004) & Montreal, Canada & Recent-PWID & Via HIV cohort study & 246 & $\geq 5-10 \mathrm{~mm}^{\mathrm{b}}$ & $22 \%$ & $5 \%$ & $\begin{array}{l}\text { Older age at first IDU, longer IDU history, } \\
\text { HIV-negative }\end{array}$ \\
\hline $\begin{array}{l}\text { Robertson } \\
(2004)\end{array}$ & San Francisco, US & $\begin{array}{l}\text { Ever-PWID, homeless and } \\
\text { marginally-housed }\end{array}$ & $\begin{array}{l}\text { Multi-stage cluster sampling at } \\
\text { homeless shelters, free-meal } \\
\text { programmes, residential hotels }\end{array}$ & 704 & $\geq 5-10 \mathrm{~mm}^{\mathrm{b}}$ & $39 \%{ }^{\mathrm{e}}$ & - & - \\
\hline Howard (2002) & New York City, US & $\begin{array}{l}\text { Ever-PWID enrolled in } \\
\text { OST }\end{array}$ & All clients invited into cohort study & 472 & $\geq 5-10 \mathrm{~mm}^{\mathrm{b}}$ & $25 \%$ & $18 \%$ & $\begin{array}{l}\text { All: TB exposure } \\
H I V \text {-: Age } \geq 35 \text {, not mainland-US born, African } \\
\text { American, home-care worker, crack use }{ }^{\mathrm{f}} \\
H I V+: \text { Puerto Rico-born, alcoholism, } \\
\text { CD4 }>500^{\mathrm{f}}\end{array}$ \\
\hline Cheung (2002) & Palo Alto, US & $\begin{array}{l}\text { Ever-PWID, homeless, in } \\
\text { residential care }\end{array}$ & All screened for TB on admission & 242 & $\geq 10 \mathrm{~mm}$ & $26 \%$ & - & None \\
\hline Riley (2002) & Baltimore, US & NSP clients & $\begin{array}{l}\text { TB services advertised but not } \\
\text { actively offered }\end{array}$ & 241 & $\geq 5-10 \mathrm{~mm}^{\mathrm{b}}$ & $17 \%$ & - & $\begin{array}{l}\text { Longer smoking history, problems affording } \\
\text { food, self-reported HIV }\end{array}$ \\
\hline Perlman (2001) & New York City, US & NSP clients & All clients offered TB screening & 974 & $\geq 5-10 \mathrm{~mm}^{\mathrm{b}}$ & $22 \%$ & - & - \\
\hline Sadaphal (2001) & Baltimore, US & PWID, 'ALIVE' cohort ${ }^{\mathrm{d}}$ & TST on enrolment, then biannually & 1238 & $\geq 5-10 \mathrm{~mm}^{\mathrm{b}}$ & $26 \%$ & - & - \\
\hline
\end{tabular}




\begin{tabular}{|c|c|c|c|c|c|c|c|c|}
\hline \multirow[t]{2}{*}{ Author } & \multirow[t]{2}{*}{ Location } & \multirow[t]{2}{*}{ Study population } & \multirow[t]{2}{*}{ Recruitment } & \multirow{2}{*}{$\begin{array}{l}\text { No. } \\
\text { PWID } \\
\text { tested }\end{array}$} & \multirow{2}{*}{$\begin{array}{c}\text { TST-positivity } \\
\text { criteria } \\
\text { (induration size) }\end{array}$} & \multicolumn{2}{|c|}{ TST-positivity } & \multirow[t]{2}{*}{ Predictive factors } \\
\hline & & & & & & All & HIV+ & \\
\hline Salomon (2000) & New York City, US & PWID NSP clients & $\begin{array}{l}\text { All clients exchanging syringes } \\
\text { offered TB screening }\end{array}$ & 564 & $\geq 10 \mathrm{~mm}$ & $15 \%$ & $17 \%$ & $\begin{array}{l}\text { Older age/longer IDU history }{ }^{\mathrm{g}} \text {, prior TST }+ \\
\text { (self-reported) }\end{array}$ \\
\hline Lorvick (1999) & San Francisco, US & PWID in HIV cohort study & Street-based targeted sampling ${ }^{\mathrm{h}}$ & 179 & $\geq 5-10 \mathrm{~mm}^{\mathrm{b}}$ & $20 \%$ & - & - \\
\hline Malotte (1999) & Long Beach, US & $\begin{array}{l}\text { PWID (current, or IDU + } \\
\text { crack in past } 90 \text { days) }\end{array}$ & Street outreach \& word of mouth & 178 & $\geq 5 \mathrm{~mm}$ & $\begin{array}{l}12- \\
23 \%\end{array}$ & - & $\begin{array}{l}\text { Age }>40 \text {, male, African American/other } \\
\text { ethnicity, unemployed, current PWID }\end{array}$ \\
\hline Rusen (1999) & Toronto, Canada & Recent-PWID NSP clients & $\begin{array}{l}\text { Clients willing to return for TST } \\
\text { reading invited }\end{array}$ & 167 & $\geq 5 \mathrm{~mm}$ & $31 \%$ & - & Older age, born outside of Canada \\
\hline Kimura (1999) & Baltimore, US & PWID, 'ALIVE' cohort ${ }^{\mathrm{d}}$ & TST on enrolment, then biannually & 467 & $\geq 5-10 \mathrm{~mm}^{\mathrm{b}}$ & $19 \%$ & $10 \%$ & - \\
\hline Robles (1998) & $\begin{array}{l}\text { San Juan, Puerto } \\
\text { Rico }\end{array}$ & $\begin{array}{l}\text { Current-PWID not enrolled } \\
\text { in OST }\end{array}$ & $\begin{array}{l}\text { Outreach cluster sampling: random } \\
\text { selection from drug-buying areas }\end{array}$ & 461 & $\geq 5-10 \mathrm{~mm}^{\mathrm{b}}$ & $19 \%$ & - & None \\
\hline Durante (1998) & New Haven, US & PWID enrolled in OST & $\begin{array}{l}\text { Clients with no history of TST }+ \text {, or of } \\
\text { TST- in past year, invited }\end{array}$ & 574 & $\geq 5-10 \mathrm{~mm}^{\mathrm{b}}$ & $17 \%$ & - & $\begin{array}{l}\text { Older age, PWID, non-white \& US-born, born } \\
\text { outside mainland US }{ }^{\text {f,j }}\end{array}$ \\
\hline Sterling (1998) & Baltimore, US & $\begin{array}{l}\text { HIV+ PWID, 'ALIVE' } \\
\text { cohort }^{\text {d }}\end{array}$ & TST on enrolment, then biannually & 182 & $\geq 5 \mathrm{~mm}$ & - & $6 \%$ & - \\
\hline Daley (1998) & San Francisco, US & PWID enrolled in OST & All clients offered TB screening & 1109 & $\geq 5-10 \mathrm{~mm}^{\mathrm{b}}$ & $39 \%$ & $28 \%$ & - \\
\hline Malotte (1998) & Long Beach, US & $\begin{array}{l}\text { PWID (current/recent, or } \\
\text { former \& now use crack) }\end{array}$ & $\begin{array}{l}\text { Street outreach \& via HIV prevention } \\
\text { project }\end{array}$ & 514 & $\geq 5 \mathrm{~mm}$ & $19 \%$ & - & $\begin{array}{l}\text { Older age, male, non-white ethnicity, cocaine in } \\
\text { urine }^{\text {f,j }}\end{array}$ \\
\hline Lifson (1997) & $\begin{array}{l}\text { Denver, Portland, } \\
\text { Oakland, SF; US }\end{array}$ & PWID, HIV cohort studies & $\begin{array}{l}\text { Community-based targeted \& } \\
\text { snowball sampling }\end{array}$ & 997 & $\geq 5-10 \mathrm{~mm}^{\mathrm{b}}$ & $13 \%$ & $13 \%$ & Older age, ethnicity, city ${ }^{\mathrm{k}}$ \\
\hline Converse (1997) & Baltimore, US & PWID, 'ALIVE' cohort ${ }^{\mathrm{d}}$ & TST on enrolment, then biannually & 65 & $\geq 5-10 \mathrm{~mm}^{\mathrm{b}}$ & $30 \%$ & $26 \%$ & - \\
\hline Manoff (1996) & Baltimore, US & PWID, 'ALIVE' cohort ${ }^{\mathrm{d}}$ & TST on enrolment, then biannually & 321 & $\geq 5 \mathrm{~mm}^{1}$ & - & $12 \%$ & Older age, male, longer IDU history ${ }^{\mathrm{m}}$ \\
\hline
\end{tabular}

'Ever', 'recent' and 'current' PWID is defined as a person who has injected drugs (PWID) ever, in the past six months and in the past month, respectively.

${ }^{\mathrm{a}}$ Data relate to period subsequent to initiation of screening intervention only (2005-7).

${ }^{\mathrm{b}}$ Cut off for HIV-positive and HIV-negative participants was $5 \mathrm{~mm}$ and $10 \mathrm{~mm}$, respectively.

${ }^{\mathrm{c}}$ Analysis relates to the entire study sample, examining association between TST-positivity and IDU among: prisoners with(out) IDU history.

d Injected at least once since 1977, aged $\geq 18$ \& AIDS-free at enrolment into cohort; community-recruited.

${ }^{\mathrm{e}}$ Includes clearly described, self-reported past positive result (these participants were not re-tested).

${ }^{\mathrm{f}}$ Analysis relates to the entire study sample, examining association between TST-positivity and IDU among: people who use drugs (injected or non-injected).

${ }^{\mathrm{g}}$ Age and duration of IDU were highly correlated and therefore modelled separately; each variable remained significant in their respective models.

${ }^{\text {h }}$ Targeted sampling: quotas set to reflect relevant demographics \& geographic areas (Watters and Biernacki, 1989); 'Snowball sampling': participants asked to refer members of their social network to the study.

${ }^{\mathrm{i}}$ The lower rate occurred among PWID who currently also used crack, and the upper rate among those who currently injected only.

${ }^{j}$ Other' ethnicity excludes Caucasian and Latino; 'non-white' ethnicity includes Latino and African American.

${ }^{\mathrm{k}}$ Analysis relates to the entire study sample, examining association between TST-positivity and IDU among: PLHIV (including PWID).

${ }^{1}$ Participants with $3-4 \mathrm{~mm}$ induration were excluded to avoid misclassification.

${ }^{\mathrm{m}}$ Univariate analysis only. 


\section{Table 2: IGRA positivity among PWID}

\begin{tabular}{|c|c|c|c|c|c|c|c|}
\hline \multirow[t]{2}{*}{ Author } & \multirow[t]{2}{*}{ Location } & \multirow[t]{2}{*}{ Study population } & \multirow[t]{2}{*}{ Recruitment } & \multirow{2}{*}{$\begin{array}{l}\text { No. } \\
\text { PWID } \\
\text { tested }\end{array}$} & \multicolumn{2}{|c|}{ IGRA-positivity } & \multirow[t]{2}{*}{ Predictive factors } \\
\hline & & & & & All & HIV+ & \\
\hline Ruutel (2011) & Johvi, Estonia & PWID enrolled in OST & All OST centre clients approached & 112 & $7.4 \%$ & $6.5 \%$ & - \\
\hline Garfein (2010) & Tijuana, Mexico & Recent-PWID, HIV-cohort study & $\begin{array}{l}\text { Street outreach, targeted advertising, } \\
\text { word of mouth }\end{array}$ & 232 & $63 \%$ & - & $\begin{array}{l}\text { Older age, increasing years in Tijuana, history } \\
\text { of prison, imprisonment in Mexico (versus US) }\end{array}$ \\
\hline Garfein (2009) & Tijuana, Mexico & Current PWID, HIV-cohort study & Respondent-driven sampling & 1020 & $64 \%{ }^{\mathrm{b}}$ & $54 \%{ }^{\mathrm{b}}$ & $\begin{array}{l}\text { Recruitment nearest US border, longer history } \\
\text { of IDU, years in Tijuana }{ }^{\text {a }}\end{array}$ \\
\hline Kimura (1999) & Baltimore, US & Ever-PWID, 'ALIVE' cohort study ${ }^{c}$ & Screened on enrolment then biannually & 467 & $45 \%$ & $19 \%$ & - \\
\hline Converse (1997) & Baltimore, US & Ever-PWID, 'ALIVE' cohort study ${ }^{c}$ & Screened on enrolment then biannually & 65 & $65 \%$ & $49 \%$ & HIV-negative status, $C D 4 \geq 200$ \\
\hline
\end{tabular}

'Ever', 'recent' and 'current' PWID defined as a person who has injected drugs ever, in the past six months and the past month, respectively.

${ }^{a}$ Protective factors: speaking some English; injecting mostly at home.

${ }^{\mathrm{b}}$ Not exclusively LTBI (13 (1.9\%) participants reported active TB symptoms); positivity rate was also weighted to adjust for respondent-driven sampling methodology.

${ }^{\mathrm{c}}$ Injected at least once since 1977 , aged $\geq 18$ \& AIDS-free at enrolment into cohort; community-recruited. 
Table 3: Prevalence of pulmonary (PTB) and extra-pulmonary TB (EPTB) among PWID

\begin{tabular}{|c|c|c|c|c|c|c|c|c|c|}
\hline \multirow[t]{2}{*}{ Author } & \multirow{2}{*}{$\begin{array}{l}\text { City, } \\
\text { Country }\end{array}$} & \multirow[t]{2}{*}{ Study population } & \multirow[t]{2}{*}{ Case detection methods } & \multirow{2}{*}{$\begin{array}{l}\text { No. } \\
\text { PWID }\end{array}$} & \multirow[t]{2}{*}{ Type of TB } & \multirow[t]{2}{*}{ Diagnostic method } & \multicolumn{2}{|c|}{ Active TB } & \multirow{2}{*}{$\begin{array}{l}\text { Predictive } \\
\text { factors }\end{array}$} \\
\hline & & & & & & & All & HIV+ & \\
\hline \multicolumn{10}{|l|}{ Europe } \\
\hline Duarte (2011) & $\begin{array}{l}\text { Vila Nova de } \\
\text { Gaia, Portugal }\end{array}$ & $\begin{array}{l}\text { Ever-PWID, attending TB } \\
\text { clinic for TST or } \\
\text { treatment }\end{array}$ & $\begin{array}{l}\text { Active \& passive: clinic record review } \\
\text { Pre screening intervention } \\
\text { Post screening intervention }\end{array}$ & $\begin{array}{l}125 \\
496\end{array}$ & $\begin{array}{l}\text { Not } \\
\text { specified }\end{array}$ & $\begin{array}{l}\text { Culture, or clinical and radiological } \\
\text { criteria }\end{array}$ & $\begin{array}{l}66 \%^{\mathrm{a}} \\
12 \%^{\mathrm{a}}\end{array}$ & - & - \\
\hline Gyarmathy (2009) & $\begin{array}{l}\text { Budapest, } \\
\text { Hungary }\end{array}$ & $\begin{array}{l}\text { Community-recruited } \\
\text { current-PWID }\end{array}$ & $\begin{array}{l}\text { Active: recruited via outreach } \& \text { chain } \\
\text { referral, all screened }\end{array}$ & 186 & $\begin{array}{l}\text { Not } \\
\text { specified }\end{array}$ & TB-Check-1 rapid test & $12 \%$ & - & Use of $\mathrm{NSP}^{\mathrm{b}}$ \\
\hline Mertz (2008) & $\begin{array}{l}\text { Basel, } \\
\text { Switzerland }\end{array}$ & $\begin{array}{l}\text { PWID admitted to } \\
\text { infectious disease ward }\end{array}$ & $\begin{array}{l}\text { Passive: referred for infectious disease } \\
\text { testing \& treatment }\end{array}$ & $344^{\mathrm{c}}$ & $\begin{array}{l}\text { Not } \\
\text { specified }\end{array}$ & $\begin{array}{l}\text { CDC case definition (citing Horan and } \\
\text { Gaynes, 2004) }\end{array}$ & $2 \%$ & - & - \\
\hline Muga (2007) & $\begin{array}{l}\text { Multiple } \\
\text { cities, Spain }\end{array}$ & $\begin{array}{l}\text { HIV+ PWID, } \\
8 \text { cohort studies }\end{array}$ & $\begin{array}{l}\text { Passive: those with TB symptoms } \\
\text { investigated for PTB \& EPTB }\end{array}$ & 1162 & $\begin{array}{l}\text { PTB and } \\
\text { EPTB }\end{array}$ & $\begin{array}{l}\text { Chest } \mathrm{x} \text {-ray and sputum analysis; } \\
\text { clinical signs/symptoms and culture }\end{array}$ & - & $12 \%$ & - \\
\hline $\begin{array}{l}\text { Caro-Murillo } \\
\text { (2007) }\end{array}$ & $\begin{array}{l}\text { Multiple } \\
\text { cities, Spain }\end{array}$ & $\begin{array}{l}\text { ART-naïve HIV+ } \\
\text { hospitalised PWID }\end{array}$ & $\begin{array}{l}\text { Passive: review of hospital diagnosis and } \\
\text { treatment records }\end{array}$ & 328 & $\begin{array}{l}\text { РTB } \\
\text { ЕРTB }\end{array}$ & 1993 European AIDS definition & - & $\begin{array}{l}6 \% \\
5 \%\end{array}$ & - \\
\hline $\begin{array}{l}\text { Sanchez- } \\
\text { Portocarrero } \\
(1996)\end{array}$ & Madrid, Spain & $\begin{array}{l}\text { PWID with HIV-related } \\
\text { neurological } \\
\text { complications }\end{array}$ & Passive: diagnoses review (hospital) & 92 & $\begin{array}{l}\text { EPTB } \\
\text { (meningitis) }\end{array}$ & Culture $(\mathrm{CSF})^{\mathrm{d}}$ & - & $13 \%$ & - \\
\hline Sanchez (1995) & Leon, Spain & Ever-PWID prisoners & $\begin{array}{l}\text { Active \& passive: inmates screened, } \\
\text { TST+ (HIV+/unknown) X-rayed; also } \\
\text { includes recently-diagnosed TB cases }\end{array}$ & 445 & РTB & $\begin{array}{l}\text { Chest x-ray followed by sputum } \\
\text { microscopy and culture }\end{array}$ & $3 \%{ }^{\mathrm{e}}$ & - & $\begin{array}{l}\text { TST }+, \text { HIV }+ \\
\text { status }\end{array}$ \\
\hline \multicolumn{10}{|l|}{ Asia } \\
\hline Solomon (2008) & Chennai, India & $\begin{array}{l}\text { HIV }+ \text { PWID, substance } \\
\text { use research centre }\end{array}$ & $\begin{array}{l}\text { Passive: chart review for opportunistic } \\
\text { infections and co-morbidities }\end{array}$ & 118 & PTB & $\begin{array}{l}\text { Radiological, clinical and/or } \\
\text { laboratory findings and history }\end{array}$ & - & $34 \%$ & CD4 $<200$ \\
\hline Alavi (2008) & Avhaz, Iran & $\begin{array}{l}\text { HIV+ PWID registered } \\
\text { with health centre }\end{array}$ & $\begin{array}{l}\text { Active: all HIV+ patients screened for } \\
\text { infectious disease screening in hospital }\end{array}$ & 40 & $\begin{array}{l}\text { PTB } \\
\text { EPTB } \\
\text { (meningitis) }\end{array}$ & $\begin{array}{l}\text { Sputum-smear microscopy and } \\
\text { clinical features } \\
\text { CSF analysis and adenosine } \\
\text { deaminase test }\end{array}$ & - & $\begin{array}{l}45 \% \\
5 \%\end{array}$ & - \\
\hline Liang (2008) & $\begin{array}{l}\text { Taipei, } \\
\text { Taiwan }\end{array}$ & $\begin{array}{l}\text { HIV+ PWID attending } \\
\text { referral HIV care centre }\end{array}$ & $\begin{array}{l}\text { Passive: patients referred for AIDS- } \\
\text { related complications }\end{array}$ & 102 & $\begin{array}{l}\text { РТВ } \\
\text { ЕРТВ }\end{array}$ & Culture & - & $\begin{array}{l}7 \% \\
10 \%\end{array}$ & - \\
\hline $\begin{array}{l}\text { Tansuphasawadikul } \\
\text { (1999) }\end{array}$ & $\begin{array}{l}\text { Bangkok, } \\
\text { Thailand }\end{array}$ & $\begin{array}{l}\text { HIV+ PWID newly- } \\
\text { admitted to hospital }\end{array}$ & $\begin{array}{l}\text { Passive: hospital-based surveillance, } \\
\text { recording all tests and diagnoses }{ }^{f}\end{array}$ & 319 & $\begin{array}{l}\text { Not } \\
\text { specified }\end{array}$ & $\begin{array}{l}1993 \text { AIDS definition (definitive \& } \\
\text { presumptive); +ve acid-fast bacilli }\end{array}$ & - & $60 \%$ & $\begin{array}{l}\text { Male gender, } \\
\text { IDU } U^{\mathrm{b}, \mathrm{g}}\end{array}$ \\
\hline Yoong (1997) & $\begin{array}{l}\text { Kuala } \\
\text { Lumpur, } \\
\text { Malaysia }\end{array}$ & $\begin{array}{l}\text { HIV+ PWID attending } \\
\text { infectious disease unit }\end{array}$ & $\begin{array}{l}\text { Active: all HIV+ patients screened for } \\
\text { AIDS-related illnesses }\end{array}$ & 49 & $\begin{array}{l}\text { РTB } \\
\text { ЕРTB }\end{array}$ & Culture & - & $\begin{array}{l}14 \% \\
4 \%\end{array}$ & - \\
\hline \multicolumn{10}{|c|}{ North and South America } \\
\hline Silveira (2006) & $\begin{array}{l}\text { Rio Grande, } \\
\text { Brazil }\end{array}$ & $\begin{array}{l}\text { HIV+ PWID attending } \\
\text { HIV clinic }\end{array}$ & $\begin{array}{l}\text { Passive: review of all diagnoses among } \\
\text { HIV clinic clients }\end{array}$ & 53 & $\begin{array}{l}\text { PTB and } \\
\text { EPTB }\end{array}$ & $\begin{array}{l}\text { Clinical profile and sputum } \\
\text { smear/culture }\end{array}$ & - & $28 \%$ & - \\
\hline
\end{tabular}




\begin{tabular}{|c|c|c|c|c|c|c|c|c|c|}
\hline \multirow[t]{2}{*}{ Author } & \multirow{2}{*}{$\begin{array}{l}\text { City, } \\
\text { Country }\end{array}$} & \multirow[t]{2}{*}{ Study population } & \multirow[t]{2}{*}{ Case detection methods } & \multirow{2}{*}{$\begin{array}{l}\text { No. } \\
\text { PWID }\end{array}$} & \multirow[t]{2}{*}{ Type of TB } & \multirow[t]{2}{*}{ Diagnostic method } & \multicolumn{2}{|c|}{ Active TB } & \multirow{2}{*}{$\begin{array}{c}\text { Predictive } \\
\text { factors }\end{array}$} \\
\hline & & & & & & & All & HIV+ & \\
\hline Sterling (1998) & Baltimore, US & $\begin{array}{l}\text { HIV+ ever PWID, } \\
\text { 'ALIVE' cohort study }\end{array}$ & $\begin{array}{l}\text { Passive: review of inpatient records \& TB } \\
\text { case registry }\end{array}$ & 182 & $\begin{array}{l}\text { PTB } \\
\text { EPTB }\end{array}$ & Culture (pulmonary, blood, other) & - & $\begin{array}{l}2 \% \\
0.5 \%\end{array}$ & - \\
\hline O’Donnell (1995) & $\begin{array}{l}\text { Washington, } \\
\text { US }\end{array}$ & $\begin{array}{l}\text { Inpatient PWID under } \\
\text { pulmonary care }\end{array}$ & Passive: review of medical charts & 69 & РTB & $\begin{array}{l}\text { Sputum smear and culture; also } \\
\text { bronchoscopy/ liver biopsy }\end{array}$ & $9 \%$ & - & - \\
\hline
\end{tabular}

'Ever', 'recent' and 'current' PWID defined as a person who has injected drugs ever, in the past six months and the past month, respectively.

a $13 \%$ cases detected via active screening prior to the intervention \& $61 \%$ after its initiation

${ }^{\mathrm{b}}$ Univariate analysis only.

${ }^{c}$ Number of hospital admissions (among 216 patients).

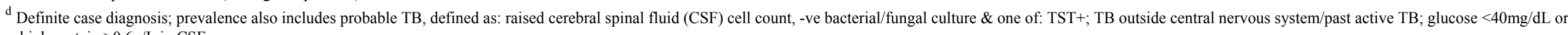
high protein $>0.6 \mathrm{~g} / \mathrm{L}$ in CSF.

${ }^{\mathrm{e}}$ Not stratified by passive/active case detection for PWID; among all prisoners, two-thirds ( $\left.\mathrm{n}=12\right)$ were recently diagnosed TB cases \& one-third were detected by active screening.

${ }^{\mathrm{f}}$ Unspecified whether patients actively screened for TB; additionally, prevalence may be an underestimate since many TB patients admitted to nearby chest hospital.

${ }^{\mathrm{g}}$ Analysis relates to all PLHIV and examines the association between active TB and IDU as route of HIV acquisition.

${ }^{\mathrm{h}}$ Injected at least once since 1977, aged $\geq 18$ \& AIDS-free at enrolment into cohort. 
Table 4: Incidence of active TB among PWID

\begin{tabular}{|c|c|c|c|c|c|c|c|c|c|}
\hline \multirow[t]{2}{*}{ Author } & \multirow[t]{2}{*}{ Dates } & \multirow[t]{2}{*}{ Location } & \multirow[t]{2}{*}{ Study population \& recruitment } & \multirow[t]{2}{*}{$\begin{array}{c}\text { No. } \\
\text { PWID }\end{array}$} & \multirow{2}{*}{$\begin{array}{c}\text { Follow-up } \\
\text { (person- } \\
\text { years) }\end{array}$} & \multirow[t]{2}{*}{ TB diagnostic method } & \multicolumn{2}{|c|}{$\begin{array}{c}\text { Incidence }(/ 1000 \\
\text { person-years })\end{array}$} & \multirow[t]{2}{*}{ Predictive factors } \\
\hline & & & & & & & All & HIV+ & \\
\hline \multicolumn{10}{|l|}{ Europe } \\
\hline $\begin{array}{l}\text { Muga } \\
(2007)\end{array}$ & $\begin{array}{l}1980 \mathrm{~s} \\
-2004\end{array}$ & Various cities, Spain & HIV+ PWID, 8 cohort studies & 1162 & 11,001 & $\begin{array}{l}\text { X-ray, sputum analysis, } \\
\text { clinical signs/symptoms } \\
\text { and culture (PTB \& EPTB) }\end{array}$ & - & 12.3 & - \\
\hline $\begin{array}{l}\text { Van Asten } \\
(2003)\end{array}$ & $\begin{array}{l}1982- \\
1998\end{array}$ & $\begin{array}{l}\text { Amsterdam, Edinburgh, } \\
\text { Geneva, Innsbruck, } \\
\text { Paris, Valencia; Europe }\end{array}$ & $\begin{array}{l}\text { HIV+ ever PWID (injected since } 1979 \text { and } \\
\text { before sero-conversion), } 7 \text { cohort studies }\end{array}$ & 683 & 3471 & $\begin{array}{l}\text { Culture, or resolution of } \\
\text { X-ray and symptoms after } \\
\text { treatment (PTB \& EPTB) }\end{array}$ & - & $11.5^{\mathrm{a}}$ & $\begin{array}{l}\text { HIV duration ( } 4-6 \& \geq 9 \mathrm{yrs}) \\
\text { CD } 4 \leq 100 \text {, city (Amsterdam/ } \\
\text { Valencia) }\end{array}$ \\
\hline $\begin{array}{l}\text { Cabarcos } \\
\text { Ortiz }(2000)\end{array}$ & $\begin{array}{l}1990- \\
1995\end{array}$ & $\begin{array}{l}\text { Santiago de } \\
\text { Compostela, Spain }\end{array}$ & HIV+ PWID at AIDS unit, screened for TB & 165 & $\begin{array}{l}\text { (av. } 25 \\
\text { months) }\end{array}$ & Culture & - & 92.5 & - \\
\hline Jansa (1998) & $\begin{array}{l}1988- \\
1992\end{array}$ & Barcelona, Spain & $\begin{array}{l}\text { PWID in residential abstinence-based drug } \\
\text { treatment, screened for TB at entry }\end{array}$ & 361 & - & $\begin{array}{l}\text { TST ( } \geq 5 \mathrm{~mm} \text {, or } \geq 15 \mathrm{~mm} \text { with } \\
\text { BCG history) and X-ray }\end{array}$ & $17.9^{\mathrm{b}}$ & 32.5 & - \\
\hline \multicolumn{10}{|c|}{ North America } \\
\hline $\begin{array}{l}\text { Golub } \\
(2008)\end{array}$ & $\begin{array}{l}1988- \\
2004\end{array}$ & Baltimore, US & $\begin{array}{l}\text { Ever PWID in 'ALIVE' cohort study; } \\
\text { biannual TST screening }\end{array}$ & 2376 & 28,770 & $\begin{array}{l}\text { TST }(\geq 5 / 10 \mathrm{~mm} \text { HIV+/-), } \\
\text { symptom review \& X-ray }\end{array}$ & 0.8 & 1.9 & HIV + , no history of prison \\
\hline $\begin{array}{l}\text { Scholten } \\
(2003)\end{array}$ & $\begin{array}{l}1993- \\
1995\end{array}$ & New York, US & $\begin{array}{l}\text { PWID OST clients; no history of } \\
\text { TB/treatment }\end{array}$ & 995 & - & CDC definition (culture) & 6.1 & 15.7 & $\begin{array}{l}\text { HIV+, IPT }<6 \text { months (versus } \\
\geq 6 \text { ), TST }+ \text { (versus anergic) }\end{array}$ \\
\hline $\begin{array}{l}\text { Jones } \\
(1998)\end{array}$ & $\begin{array}{l}1991- \\
1996\end{array}$ & Various cities; US & $\begin{array}{l}\text { HIV+ PWID with } 13 \text { most common } \\
\text { opportunistic infections, reported via } \\
\text { surveillance system }\end{array}$ & 4475 & 7383 & $\begin{array}{l}\text { CDC definitive and } \\
\text { presumptive criteria }\end{array}$ & - & $31.0^{\mathrm{c}}$ & - \\
\hline $\begin{array}{l}\text { Daley } \\
(1998)\end{array}$ & $\begin{array}{l}1990- \\
1994\end{array}$ & San Francisco, US & HIV+ PWID OST clients screened for TB & 1109 & 2340 & $\begin{array}{l}1990 \text { CDC definition } \\
\text { (culture) }\end{array}$ & 3.4 & 7.3 & $\begin{array}{l}H I V+\text { and TST+ participants: } \\
\text { no history of IPT }\end{array}$ \\
\hline $\begin{array}{l}\text { Markowitz } \\
\text { (1997) }\end{array}$ & $\begin{array}{l}1990- \\
1994\end{array}$ & Various cities;; US & $\begin{array}{l}\text { AIDS-free HIV+ PWID, multiple health } \\
\text { centres }\end{array}$ & 261 & $\begin{array}{l}\text { (av. } 53 \\
\text { months) }\end{array}$ & 1990 CDC definition & - & 17.0 & $\begin{array}{l}\text { Residence in Eastern US, TST }+ \text {, } \\
\text { TST } \geq 20 \mathrm{~mm}^{\mathrm{d}, \mathrm{e}}\end{array}$ \\
\hline $\begin{array}{l}\text { Rubinstein } \\
\text { (1996) }\end{array}$ & $\begin{array}{l}1984- \\
1992\end{array}$ & $\begin{array}{l}\text { Hartford, Connecticut, } \\
\text { US }\end{array}$ & HIV+ PWID at hospital health centre & 732 & $\begin{array}{l}\text { (av. } 3.4 \\
\text { years) }\end{array}$ & $\begin{array}{l}\text { Culture/strong clinical } \\
\text { grounds }\end{array}$ & - & 6.0 & None \\
\hline $\begin{array}{l}\text { Graham } \\
(1996)\end{array}$ & $\begin{array}{l}1988- \\
1994\end{array}$ & Baltimore, US & $\begin{array}{l}\text { Ever-PWID in 'ALIVE' cohort study; } \\
\text { biannual TST }\end{array}$ & 2960 & & $\begin{array}{l}\text { Cases reported via city } \\
\text { surveillance system }\end{array}$ & 1.0 & 1.9 & HIV+ status ${ }^{\mathrm{d}}$; CD4 (HIV+ only) \\
\hline \multicolumn{10}{|c|}{ Europe \& North America } \\
\hline $\begin{array}{l}\text { Girardi } \\
(2005)\end{array}$ & $\begin{array}{l}1996- \\
2003\end{array}$ & $\begin{array}{l}\text { Western Europe and } \\
\text { North America }\end{array}$ & $\begin{array}{l}\text { AIDS-free HIV+ PWID starting ART } \\
\text { (treatment-naïve), } 12 \text { cohort studies }\end{array}$ & 2890 & 6084 & $\begin{array}{l}1992 \text { CDC AIDS } \\
\text { definition (PTB only) }\end{array}$ & - & 5.3 & $\begin{array}{l}\text { Low baseline \& 6-month CD4, } \\
6 \text {-month HIV RNA }>400, \text { more } \\
\text { recent \& shorter history of ART }\end{array}$ \\
\hline
\end{tabular}

'Ever', 'recent' and 'current' PWID defined as a person who has injected drugs ever, in the past six months and the past month, respectively.

${ }^{\text {a }}$ Incidence of first TB diagnosis only.

${ }^{b}$ Almost all participants were $\mathrm{HIV}+(355 / 361)$.

${ }^{\mathrm{C}}$ Incidence of first (E)PTB occurrence as opportunistic infection.

${ }^{\mathrm{d}}$ Univariate analysis only.

${ }^{\mathrm{e}}$ Analysis relates to all PLHIV, examining the association between TB incidence and history of IDU (as route of HIV acquisition). 
Table 5: Proportion of TB among AIDS-defining diagnoses in PWID

\begin{tabular}{|c|c|c|c|c|c|c|c|c|}
\hline Author & Year(s) & City, country & Study Population & $\begin{array}{l}\text { No. } \\
\text { PWID }\end{array}$ & Type of TB & TB/AIDS definition & $\%$ TB & Predictive factors for $\mathbf{T B}^{\mathrm{a}}$ \\
\hline \multicolumn{9}{|l|}{ Europe } \\
\hline $\begin{array}{l}\text { Godoy } \\
(1998)\end{array}$ & 1994 & Lleida, Spain & $\begin{array}{l}\text { PWID cases reported to national AIDS } \\
\text { register }\end{array}$ & 4529 & $\begin{array}{l}\text { PTB and } \\
\text { EPTB }\end{array}$ & 1993 European AIDS definition & $48 \%$ & $\begin{array}{l}\text { Male, age }<30 \text {, IDU (versus MSM/other), ever } \\
\text { in prison }\end{array}$ \\
\hline $\begin{array}{l}\text { Vall } \\
\text { Mayans } \\
(1997)\end{array}$ & $\begin{array}{l}1988- \\
1994\end{array}$ & $\begin{array}{l}\text { Catalonia, } \\
\text { Spain }\end{array}$ & Cases reported to regional AIDS registry & 4274 & Not specified & $\begin{array}{l}\text { 1985/1987 CDC and } 1993 \\
\text { European AIDS definitions }\end{array}$ & $31 \%$ & $\begin{array}{l}\text { Younger age, male, resident in city, IDU, ever } \\
\text { in prison }^{\text {bc }}\end{array}$ \\
\hline $\begin{array}{l}\text { Castilla } \\
(1997)\end{array}$ & 1995 & $\begin{array}{l}\text { Nationwide, } \\
\text { Spain }\end{array}$ & $\begin{array}{l}\text { PWID AIDS cases identified by national } \\
\text { surveillance system }\end{array}$ & 3963 & $\begin{array}{l}\text { PTB and } \\
\text { EPTB }\end{array}$ & 1993 European AIDS definition & $45 \%$ & Currently/ever in prison; IDU ${ }^{\mathrm{b}}$ \\
\hline $\begin{array}{l}\text { Triol } \\
(1996)\end{array}$ & $\begin{array}{l}1988- \\
1993\end{array}$ & $\begin{array}{l}\text { Nationwide, } \\
\text { France }\end{array}$ & $\begin{array}{l}\text { PWID cases reported to national AIDS } \\
\text { register }\end{array}$ & $\begin{array}{l}4930 \\
991\end{array}$ & $\begin{array}{l}\text { EPTB } \\
\text { PTB and } \\
\text { EPTB }\end{array}$ & $\begin{array}{l}1987 \text { CDC and } 1993 \text { European } \\
\text { AIDS definitions (culture or } \\
\text { clinical/radiological diagnosis) }\end{array}$ & $\begin{array}{l}9 \% \\
14 \%\end{array}$ & $\begin{array}{l}\text { All }{ }^{\mathrm{b}} \text { : IDU/heterosexual, non-French nationality, } \\
\text { Paris resident } \\
E P T B^{\mathrm{b}}: \text { male, manual labour/ unemployed }\end{array}$ \\
\hline $\begin{array}{l}\text { Schwoebel } \\
(1995)\end{array}$ & $\begin{array}{l}1988- \\
1992\end{array}$ & $\begin{array}{l}9 \text { countries, } \\
\text { W. Europe }\end{array}$ & $\begin{array}{l}\text { PWID AIDS cases reported to European } \\
\text { surveillance system }\end{array}$ & 14,788 & ЕРТВ & 1987 CDC AIDS definition & $6 \%$ & $\begin{array}{l}\text { Male, age }<30 \text {, country (highest in Portugal } \\
\text { versus UK), IDU/other (versus MSM) }\end{array}$ \\
\hline $\begin{array}{l}\text { Cayla } \\
(1995)\end{array}$ & $\begin{array}{l}1988- \\
1993\end{array}$ & $\begin{array}{l}\text { Barcelona, } \\
\text { Spain }\end{array}$ & $\begin{array}{l}\text { PWID AIDS cases reported to European } \\
\text { surveillance system }\end{array}$ & 1182 & ЕРТВ & 1987 CDC AIDS definition & $27 \%$ & Ever in prison ${ }^{\mathrm{e}}$ \\
\hline $\begin{array}{l}\text { Castilla } \\
(1995)\end{array}$ & $\begin{array}{l}1988- \\
1993\end{array}$ & $\begin{array}{l}\text { Nationwide, } \\
\text { Spain }\end{array}$ & $\begin{array}{l}\text { PWID AIDS cases identified by national } \\
\text { surveillance system }\end{array}$ & 14,464 & ЕРТВ & 1987 CDC AIDS definition & $35 \%$ & $\begin{array}{l}\text { Male, age }<30 \text {, ever in prison, high provincial } \\
\text { TB mortality, earlier diagnosis }\end{array}$ \\
\hline \multicolumn{9}{|c|}{ Other regions } \\
\hline $\begin{array}{l}\text { Amill } \\
(2004)\end{array}$ & $\begin{array}{l}1992- \\
2000\end{array}$ & $\begin{array}{l}\text { Bayamon, } \\
\text { Puerto Rico }\end{array}$ & $\begin{array}{l}\text { Male PWID AIDS patients at health } \\
\text { centres }\end{array}$ & 610 & РТВ & 1992 CDC AIDS definition & $5 \%$ & $\begin{array}{l}\text { Male, lower education, HIV transmission } \\
\text { (highest risk in PWID), region, older age }\end{array}$ \\
\hline $\begin{array}{l}\text { Laguardia } \\
\text { (2003) }\end{array}$ & $\begin{array}{l}1980- \\
2000\end{array}$ & $\begin{array}{l}\text { Nationwide, } \\
\text { Brazil }\end{array}$ & $\begin{array}{l}\text { PWID AIDS cases reported to Ministry of } \\
\text { Health }\end{array}$ & 34,752 & $\begin{array}{l}\text { PTB and } \\
\text { EPTB }\end{array}$ & $\begin{array}{l}\text { National AIDS surveillance } \\
\text { definition (as CDC 1987/1992) }\end{array}$ & $33 \%$ & - \\
\hline $\begin{array}{l}\text { Chariyalertsak } \\
(2001)\end{array}$ & $\begin{array}{l}1994- \\
1998\end{array}$ & $\begin{array}{l}\text { Various, } \\
\text { Thailand }\end{array}$ & $\begin{array}{l}\text { PWID AIDS cases reported via national } \\
\text { surveillance system }\end{array}$ & 5383 & Not specified & $\begin{array}{l}1992 \text { CDC AIDS definition } \\
\text { (laboratory confirmation) }\end{array}$ & $48 \%$ & - \\
\hline $\begin{array}{l}\text { Jones } \\
(1996)\end{array}$ & 1993 & $\begin{array}{l}\text { Nationwide, } \\
\text { US }\end{array}$ & $\begin{array}{l}\text { PWID AIDS cases reported via local, } \\
\text { territorial and state surveillance systems }\end{array}$ & 20,593 & $\begin{array}{l}\text { PTB and } \\
\text { EPTB }\end{array}$ & $\begin{array}{l}1987 \text { and } 1992 \text { CDC AIDS } \\
\text { definitions }\end{array}$ & $8 \%$ & $\begin{array}{l}\text { Black/Hispanic (versus White) ethnicity, } \\
\text { IDU/heterosexual (versus MSM), non-US } \\
\text { born }^{\text {b }}\end{array}$ \\
\hline
\end{tabular}

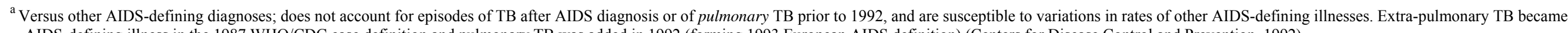
AIDS-defining illness in the 1987 WHO/CDC case definition and pulmonary TB was added in 1992 (forming 1993 European AIDS definition) (Centers for Disease Control and Prevention, 1992).

${ }^{\mathrm{b}}$ Analysis relates to all AIDS cases, including PWID, examining effects of HIV transmission route (IDU, sex between men (MSM) and heterosexual sex).

${ }^{\mathrm{c}}$ Interaction between IDU and history of prison (IDU increased risk of TB among those without experience of prison, compared to those with).

${ }^{\mathrm{d}}$ Excludes heterosexually-acquired HIV in cases where partner originates from region in which heterosexual HIV transmission is common.

${ }^{\mathrm{e}}$ Analysis compares occurrence of TB as AIDS-defining illness with that of Pneumocystis pneumonia (PCP). 
Table 6: Proportion of MDR-TB among PWID with active TB

\begin{tabular}{|c|c|c|c|c|c|c|c|c|}
\hline \multirow[t]{2}{*}{ Author } & \multirow[t]{2}{*}{ Location } & \multirow[t]{2}{*}{ Study population } & \multirow[t]{2}{*}{ Recruitment method } & \multirow{2}{*}{$\begin{array}{l}\text { No. PWID } \\
\text { tested }\end{array}$} & \multirow[t]{2}{*}{ Diagnosis of MDR-TB ${ }^{\mathrm{a}}$} & \multicolumn{2}{|c|}{$\%$ (n) MDR-TB cases ${ }^{b}$} & \multirow{2}{*}{$\begin{array}{l}\text { Association between } \\
\text { IDU and MDR-TB }\end{array}$} \\
\hline & & & & & & PWID & All TB & \\
\hline $\begin{array}{l}\text { Akksilp } \\
(2009)\end{array}$ & Thailand & $\begin{array}{l}\text { Ever-PWID TB patients } \\
\text { treated in public TB } \\
\text { clinics }\end{array}$ & $\begin{array}{l}\text { Review of medical records, } \\
\text { via national surveillance } \\
\text { network }\end{array}$ & 329 & $\begin{array}{l}\geq 1 \text { sputum sample for culture } \& \text { drug-susceptibility } \\
\text { testing (national reference lab.) }{ }^{\mathrm{c}}\end{array}$ & $4.0 \%$ & $1.4 \%(145)$ & $\begin{array}{l}\text { Increased risk } \\
(\text { Odds ratio }=3.1)^{\mathrm{d}}\end{array}$ \\
\hline $\begin{array}{l}\text { Suarez- } \\
\text { Garcia } \\
(2009)\end{array}$ & $\begin{array}{l}\text { Madrid, } \\
\text { Spain }\end{array}$ & $\begin{array}{l}\text { Ever-PWID TB patients } \\
\text { at TB clinics }\end{array}$ & $\begin{array}{l}\text { Review of medical records } \\
\text { at } \mathrm{TB} \text { clinic }\end{array}$ & 83 & $\begin{array}{l}\text { Drug susceptibility testing on sputum cultures - } \\
\text { conducted/confirmed by national reference lab. }\end{array}$ & $4.8 \%$ & $4.5 \%(30)$ & No \\
\hline $\begin{array}{l}\text { Shamaei } \\
(2009)\end{array}$ & Tehran, Iran & $\begin{array}{l}\text { Ever-PWID TB in- } \\
\text { patients }\end{array}$ & $\begin{array}{l}\text { Review of medical records } \\
\text { at TB reference centre } \\
\text { hospital }\end{array}$ & 35 & $\begin{array}{l}\text { Positive sputum smear/culture, or histo-pathological } \\
\text { features and clinical response to anti-TB medication. } \\
\text { Drug susceptibility testing by proportional method }\end{array}$ & $2.9 \%$ & $1.1 \%(10)$ & No \\
\hline $\begin{array}{l}\text { Mdivani } \\
(2008)\end{array}$ & $\begin{array}{l}\text { Various } \\
\text { cities, } \\
\text { Georgia }\end{array}$ & Ever-PWID TB patients & $\begin{array}{l}\text { Cross-sectional survey of } \\
\text { inpatients at four sentinel } \\
\text { surveillance sites }\end{array}$ & 22 & $\begin{array}{l}\text { Three sputum samples for acid-fast bacilli and } \\
\text { culture. Drug susceptibility testing by national } \\
\text { reference lab. (absolute concentration method) }\end{array}$ & $68 \%$ & $28 \%(262)$ & $\begin{array}{l}\text { Increased risk } \\
(\text { Prevalence ratio }=1.6)\end{array}$ \\
\hline $\begin{array}{l}\text { Banerjee } \\
(2008)\end{array}$ & $\begin{array}{l}\text { California, } \\
\text { US }\end{array}$ & Ever-PWID TB cases & $\begin{array}{l}\text { Cases reported to state TB } \\
\text { registry, via routine } \\
\text { surveillance system }\end{array}$ & 1276 & $\begin{array}{l}\text { Drug susceptibility testing on isolates at local, state } \\
\text { and CDC laboratories }\end{array}$ & $0.8 \%$ & $1.6 \%(627)$ & Reduced risk $^{\mathrm{e}}$ \\
\hline $\begin{array}{l}\text { Liang } \\
(2008)\end{array}$ & $\begin{array}{l}\text { Taipei, } \\
\text { Taiwan }\end{array}$ & $\begin{array}{l}\text { HIV+ PWID TB } \\
\text { patients at referral HIV } \\
\text { care centre }\end{array}$ & $\begin{array}{l}\text { Review of medical records } \\
\text { at HIV care centre }\end{array}$ & 17 & $\begin{array}{l}\text { Isolation of M. tuberculosis resistant to isoniazid and } \\
\text { rifampin }\end{array}$ & $11.8 \%$ & - & - \\
\hline Liu (1998) & $\begin{array}{l}\text { New Jersey, } \\
\text { US }\end{array}$ & $\begin{array}{l}\text { Recent-PWID TB cases } \\
\text { (IDU in past year) }\end{array}$ & $\begin{array}{l}\text { TB cases reported via } \\
\text { expanded surveillance } \\
\text { system }\end{array}$ & 152 & $\begin{array}{l}\text { Drug susceptibility testing, results reported to state } \\
\text { health department }\end{array}$ & $3.3 \%$ & $2.9 \%$ & No \\
\hline
\end{tabular}

${ }^{\mathrm{a}} \mathrm{MDR}$ (multidrug resistance) $=$ resistance to at least izoniazid and rifampicin

${ }^{\mathbf{b}}$ Typically calculated from available data on the prevalence of reported IDU among TB and MDR-TB patients.

${ }^{\mathrm{c}}$ Encouraged but not required under the national surveillance network.

${ }^{\mathrm{d}}$ Odds ratio relates to PWID new patients only and excludes patients with missing MDR-TB status.

${ }^{\mathrm{e}}$ Univariate analysis only; MDR-TB cases less likely to have history of IDU, incarceration or homelessness and more likely to be foreign-born, have prior TB diagnosis and shorter between entry into US and diagnosis. 


\section{Table 7: Models of TB care for PWID}

\begin{tabular}{|c|c|c|c|c|c|c|c|}
\hline Author (Year) & Dates & Location & Population & Intervention / model of care & Drug treatment & HIV \& HCV care & Evaluation method \\
\hline \multicolumn{8}{|c|}{ 1. TB screening and prevention within PWID HIV risk studies } \\
\hline Golub (2008) & $\begin{array}{l}1990- \\
1998\end{array}$ & $\begin{array}{l}\text { Baltimore, } \\
\text { US }\end{array}$ & $\begin{array}{l}\text { HIV }+\& \text { at-risk } \\
\text { PWID, 'ALIVE' } \\
\text { cohort study }\end{array}$ & $\begin{array}{l}\text { Screening: TST on entry then biannually, at study clinic; active TB screening } \\
\text { (location unspecified). Prevention: } 6 \text { months IPT, self-administered in } 1^{\text {st }} \text { year, } \\
\text { then DOPT } 2-3 \text { times per week (eligibility: TST }+ \text { without active TB). }\end{array}$ & None & $\begin{array}{l}\text { 6-monthly HIV } \\
\text { testing and } \\
\text { monitoring }\end{array}$ & $\begin{array}{l}\text { Comparison of TB } \\
\text { incidence (pre/post) }\end{array}$ \\
\hline $\begin{array}{l}\text { Graham } \\
(1996)\end{array}$ & $\begin{array}{l}1988- \\
1994\end{array}$ & $\begin{array}{l}\text { Baltimore, } \\
\text { US }\end{array}$ & $\begin{array}{l}\text { PWID in 'ALIVE' } \\
\text { cohort study, not } \\
\text { in drug treatment }\end{array}$ & $\begin{array}{l}\text { Screening: TST on entry then biannually, at study clinic; active TB screening } \\
\text { (location unspecified). Prevention: From 1992, } 6 \text { months IPT; self-administered } \\
\text { in } 1^{\text {st }} \text { year self-administered, then DOPT twice per week. Extended to } 12 \\
\text { months if compliant (eligibility: TST+ without active TB). }\end{array}$ & None & $\begin{array}{l}\text { 6-monthly HIV } \\
\text { testing and } \\
\text { monitoring }\end{array}$ & $\begin{array}{l}\text { Description of IPT } \\
\text { completion and TB } \\
\text { incidence }\end{array}$ \\
\hline $\begin{array}{l}\text { Malotte } \\
\text { (1998) }\end{array}$ & $\begin{array}{l}1994- \\
1995\end{array}$ & $\begin{array}{l}\text { Long } \\
\text { Beach, } \\
\text { California, } \\
\text { US }\end{array}$ & $\begin{array}{l}\text { Current PWID/ } \\
\text { crack users not in } \\
\text { treatment, no prior } \\
\text { TST+ }\end{array}$ & $\begin{array}{l}\text { Screening: TST with nurse-led motivational education and incentives (on } \\
\text { return) to improve return for reading. Outreach teams trained in TST and } \\
\text { followed up non-return. } 5 \text { intervention groups: (1) education only; (2) } \$ 5 \text { cash; } \\
\text { (3) } \$ 5 \text { cash + education; (4) } \$ 10 \text { cash; (5) } \$ 10 \text { cash + education. }\end{array}$ & None & None specified & $\begin{array}{l}\text { RCT comparing TST } \\
\text { return among } \\
\text { intervention groups }\end{array}$ \\
\hline $\begin{array}{l}\text { Malotte } \\
\text { (1999) }\end{array}$ & $\begin{array}{l}1995- \\
1997\end{array}$ & $\begin{array}{l}\text { Long } \\
\text { Beach, } \\
\text { California, } \\
\text { US }\end{array}$ & $\begin{array}{l}\text { Current PWID/ } \\
\text { crack users not in } \\
\text { treatment, no prior } \\
\text { TST+ }\end{array}$ & $\begin{array}{l}\text { Screening: TST with nurse-led motivational education or incentives (on return) } \\
\text { to improve return for reading. Outreach teams followed up non-return. } 4 \\
\text { intervention groups: (1) education session only; (2) choice of } \$ 10 \text { fast- } \\
\text { food/travel tokens; (3) } \$ 10 \text { supermarket voucher; (4) } \$ 10 \text { cash. }\end{array}$ & None & $\begin{array}{l}\text { HIV testing and } \\
\text { counselling if no } \\
\text { test in past } 6 \\
\text { months }\end{array}$ & $\begin{array}{l}\text { RCT comparing TST } \\
\text { return among } \\
\text { intervention groups }\end{array}$ \\
\hline Lifson (1997) & - & $\begin{array}{l}\text { Various } \\
\text { cities; US }\end{array}$ & $\begin{array}{l}\text { PWID; no history } \\
\text { of TST }+ \text { or active } \\
\text { TB/ treatment }\end{array}$ & $\begin{array}{l}\text { Screening: Incentivised } 2 \text {-step TST to improve LTBI detection. Incentives: } \$ 10 \text { - } \\
20 \text { for TST placement, } \$ 10 \text { on return. Referral for medical evaluation if TST+. } \\
\text { TB and TST training for staff at all sites. }\end{array}$ & None & $\begin{array}{l}\text { HIV testing on entry } \\
\text { into HIV cohort } \\
\text { studies }\end{array}$ & $\begin{array}{l}\text { Description of } 1^{\text {st }} \text { and } \\
2^{\text {nd }} \text { TST return }\end{array}$ \\
\hline $\begin{array}{l}\text { Swaminathan } \\
(2007)\end{array}$ & $\begin{array}{l}1993- \\
1995\end{array}$ & $\begin{array}{l}\text { New York, } \\
\text { US }\end{array}$ & $\begin{array}{l}\text { Current/ former } \\
\text { PWUD }\end{array}$ & $\begin{array}{l}\text { Screening: Incentivised 2-step TST at study site, to improve LTBI detection } \\
\text { (incentive amount unspecified). Referral for medical evaluation if TST+. }\end{array}$ & $\begin{array}{l}\text { None (recruited } \\
\text { via OST centre) }\end{array}$ & - & $\begin{array}{l}\text { Description of } 1^{\text {st }} \text { and } \\
2^{\text {nd }} \text { TST return }\end{array}$ \\
\hline $\begin{array}{l}\text { Lorvick } \\
\text { (1999) }\end{array}$ & - & $\begin{array}{l}\text { San } \\
\text { Francisco, } \\
\text { US }\end{array}$ & $\begin{array}{l}\text { PWID eligible for } \\
\text { IPT }\end{array}$ & $\begin{array}{l}\text { Screening: Incentivised TST (Lifson et al., 1997) \& active TB screening via } \\
\text { onsite mobile X-ray unit. } \$ 10 \text { for TST return; } \$ 10 \text { for active screening. Referral } \\
\text { to other services as needed. Prevention: Incentivised 6-month DOPT, } 2 x / \text { week } \\
\text { at drop-in centre, with city TB clinic. Incentives: } \$ 10 \text { cash at start and per visit. }\end{array}$ & $\begin{array}{l}\text { Referral to drug } \\
\text { treatment } \\
\text { services where } \\
\text { needed }\end{array}$ & $\begin{array}{l}\text { Nested within HIV } \\
\text { sero-prevalence } \\
\text { study }\end{array}$ & $\begin{array}{l}\text { Description of TST } \\
\text { uptake and return }\end{array}$ \\
\hline $\begin{array}{l}\text { Malotte } \\
(2001)\end{array}$ & $\begin{array}{l}1994- \\
1997\end{array}$ & $\begin{array}{l}\text { Long } \\
\text { Beach, } \\
\text { California, } \\
\text { US }\end{array}$ & $\begin{array}{l}\text { Current/recent } \\
\text { PWID or crack } \\
\text { users, not in drug } \\
\text { treatment }\end{array}$ & $\begin{array}{l}\text { Screening: TST (active TB screening location unspecified). } \\
\text { Prevention: } 6-12 \text { months DOPT, } 2 x / \text { week at study site or via outreach, with(out) } \\
\text { incentives. } 4 \text { intervention groups: (1-2) outreach DOPT in chosen location, } \\
\text { with(out) } \$ 5 \text { per visit ; (3) DOPT at study site, } \$ 5 \text { per visit. }\end{array}$ & None & $\begin{array}{l}\text { Co-located with } \\
\text { HIV risk reduction } \\
\text { project }\end{array}$ & $\begin{array}{l}\text { RCT comparing IPT } \\
\text { adherence ('on-time') } \\
\text { and completion }\end{array}$ \\
\hline \multicolumn{8}{|c|}{ 2. TB prevention for PWID at TB clinics } \\
\hline $\begin{array}{l}\text { Chaisson } \\
(2001)\end{array}$ & $\begin{array}{l}1995- \\
1997\end{array}$ & $\begin{array}{l}\text { Baltimore, } \\
\text { US }\end{array}$ & $\begin{array}{l}\text { PWID (IDU past } 3 \\
\text { months, or longer } \\
\text { if on OST) }\end{array}$ & $\begin{array}{l}\text { Prevention: } 6 \text { months IPT, DOPT or take-home, with(out) peer counselling } \\
\text { (eligibility: TST+ and no active TB). } 3 \text { intervention groups: (1) DOPT } 2 x / \text { week } \\
\text { at TB clinic; (2) self-administered IPT + peer counselling; (3) routine care: self- } \\
\text { administered IPT only. Incentives: immediate/deferred \$10/month. }\end{array}$ & None $^{\mathrm{a}}$ & $\begin{array}{l}\text { HIV prevention and } \\
\text { treatment education } \\
\text { (peer counsellors) }\end{array}$ & $\begin{array}{l}\text { RCT comparing IPT } \\
\text { adherence and } \\
\text { completion }\end{array}$ \\
\hline \multirow{2}{*}{\multicolumn{8}{|c|}{ 3. TB screening and prevention within NSP and drug treatment services, with referral for active screening }} \\
\hline & & & & & & & \\
\hline Riley (2002) & $\begin{array}{l}1998- \\
1999\end{array}$ & $\begin{array}{l}\text { Baltimore, } \\
\text { US }\end{array}$ & $\begin{array}{l}\text { NSP clients } \\
\text { seeking advertised } \\
\text { TB services }\end{array}$ & $\begin{array}{l}\text { Screening: Incentivised TST at NSP; promoted but not actively offered. } \\
\text { Incentives: } \$ 5 \text { cheque + travel tokens for TST return. Referral for active TB } \\
\text { screening. Prevention and treatment: on-site IPT; DOTS onsite/by referral (re. } \\
\text { clients' preference); TB education. }\end{array}$ & None & $\begin{array}{l}\text { HIV testing and } \\
\text { counselling onsite }\end{array}$ & $\begin{array}{l}\text { Regression analysis: } \\
\text { factors associated } \\
\text { with TST return }\end{array}$ \\
\hline
\end{tabular}




\begin{tabular}{|c|c|c|c|c|c|c|c|}
\hline Author (Year) & Dates & Location & Population & Intervention / model of care & Drug treatment & HIV \& HCV care & Evaluation method \\
\hline $\begin{array}{l}\text { Perlman } \\
\text { (1997), Paone } \\
\text { (1998), } \\
\text { Salomon } \\
\text { (1999) }\end{array}$ & $\begin{array}{l}1995- \\
1996\end{array}$ & $\begin{array}{l}\text { New York, } \\
\text { US }\end{array}$ & NSP clients & $\begin{array}{l}\text { Screening: Incentivised TST offered to all NSP clients. Incentives: } \$ 10 \text { cash + } \\
\$ 5 \text { travel tokens for TST return. Referral to health centre for active TB } \\
\text { screening. Prevention and treatment: on-site IPT; referral to health centre for } \\
\text { DOTS; support securing health insurance (social work interns). }\end{array}$ & None & $\begin{array}{l}\text { HIV testing and } \\
\text { counselling onsite }\end{array}$ & $\begin{array}{l}\text { Description of TST } \\
\text { uptake and return }\end{array}$ \\
\hline $\begin{array}{l}\text { Fitzgerald } \\
(1999)\end{array}$ & 1996 & $\begin{array}{l}\text { Vancouver, } \\
\text { Canada }\end{array}$ & $\begin{array}{l}\text { NSP clients in } \\
\text { HIV risk study }\end{array}$ & $\begin{array}{l}\text { Screening: Incentivised TST offered to all NSP clients. Incentives: } \$ 5 \text { (Can) on } \\
\text { TST return. Active TB screening (X-ray and sputum); location unspecified. }\end{array}$ & None & Part of HIV study & $\begin{array}{l}\text { Comparison of TST } \\
\text { return (pre/post) }\end{array}$ \\
\hline Rusen (1999) & 1996 & $\begin{array}{l}\text { Toronto, } \\
\text { Canada }\end{array}$ & $\begin{array}{l}\text { Recent PWID } \\
\text { NSP clients }\end{array}$ & $\begin{array}{l}\text { Screening: Incentivised TST offered to all NSP clients willing to return for test } \\
\text { reading. Incentives: } \$ 10 \text { for TST placement and interview, } \$ 15 \text { on TST return. } \\
\text { Referral to TB clinic for active screening (see below). }\end{array}$ & None & None specified & $\begin{array}{l}\text { Description of TST } \\
\text { return }\end{array}$ \\
\hline \multicolumn{8}{|c|}{ Drug dependency treatment programmes } \\
\hline $\begin{array}{l}\text { Gourevitch } \\
(1996)\end{array}$ & $\begin{array}{l}1991 \\
- \\
1992\end{array}$ & $\begin{array}{l}\text { New York, } \\
\text { US }\end{array}$ & $\begin{array}{l}\text { Methadone } \\
\text { programme clients }\end{array}$ & $\begin{array}{l}\text { TB screening and prevention at co-located primary care \& substance use centre. } \\
\text { TST on entry then annually; active TB screening (clinical and culture). 6-12 } \\
\text { months DOPT for those with current/past TST+ (HIV-: } 6 \text { months; } \\
\text { HIV+/unknown: } 12 \text { months). Also onsite TB treatment (see model 6, below). }\end{array}$ & $\begin{array}{l}\text { Existing OST } \\
\text { programme }\end{array}$ & $\begin{array}{l}\text { HIV testing offered } \\
\text { onsite }\end{array}$ & $\begin{array}{l}\text { Description of IPT } \\
\text { completion and } \\
\text { retention }\end{array}$ \\
\hline $\begin{array}{l}\text { Gourevitch } \\
(1999)\end{array}$ & $\begin{array}{l}1985 \\
- \\
1996\end{array}$ & $\begin{array}{l}\text { New York, } \\
\text { US }\end{array}$ & $\begin{array}{l}\text { Methadone } \\
\text { programme clients }\end{array}$ & $\begin{array}{l}\text { Screening and prevention: annual TST and 12- months daily IPT with } \\
\text { methadone, offered under direct observation at co-located primary care and } \\
\text { substance use centre (IPT eligibility: TST+/anergic, or history of TST+ but not } \\
\text { IPT/TB treatment). Surveillance of confirmed active TB via hospital records/ } \\
\text { notifications to OST centre, city TB register, client reports. }\end{array}$ & $\begin{array}{l}\text { Existing OST } \\
\text { programme }\end{array}$ & $\begin{array}{l}\text { HIV testing; } \\
\text { biannual CD4 } \\
\text { monitoring } \\
\text { (concurrent HIV } \\
\text { study) }\end{array}$ & $\begin{array}{l}\text { Comparison of TB } \\
\text { incidence by IPT } \\
\text { completion }\end{array}$ \\
\hline $\begin{array}{l}\text { Scholten } \\
(2003)\end{array}$ & $\begin{array}{l}1993- \\
1995\end{array}$ & $\begin{array}{l}\text { New York, } \\
\text { US }\end{array}$ & $\begin{array}{l}\text { PWID methadone } \\
\text { clients }\end{array}$ & $\begin{array}{l}\text { Screening and prevention: TST; } 6-12 \text { months DOPT with methadone } \& \text { vitamin } \\
\text { B6 (daily/2-3x per week), observed by nurse at OST centre. In collaboration } \\
\text { with TB control programme (IPT eligibility: high risk of TB }{ }^{\mathrm{b}} \text {, no history of } \\
\text { active TB). TST+ \& HIV-: } 6 \text { months; TST+/anergic and HIV+: } 12 \text { months. }\end{array}$ & $\begin{array}{l}\text { Existing OST } \\
\text { programme }\end{array}$ & $\begin{array}{l}\text { Full medical } \\
\text { evaluation at entry, } \\
\text { including HCV } \\
\text { screening }\end{array}$ & $\begin{array}{l}\text { Observational: } \\
\text { association between } \\
\text { IPT completion and } \\
\text { TB incidence }\end{array}$ \\
\hline Bakti (2002) & $\begin{array}{l}1995- \\
1996\end{array}$ & $\begin{array}{l}\text { San } \\
\text { Francisco, } \\
\text { US }\end{array}$ & $\begin{array}{l}\text { HIV-ve PWID } \\
\text { with LTBI, in } \\
\text { methadone detox. }\end{array}$ & $\begin{array}{l}\text { Prevention: } 6 \text { months IPT with(out) OST and substance use counselling, at } \\
\text { methadone detox. programme. } 3 \text { intervention groups: (1) daily DOPT + } \\
\text { methadone, with counselling; (2) daily DOPT + methadone, no counselling; (3) } \\
\text { routine TB care: referral to TB clinic, monthly IPT collection (no OST). }\end{array}$ & $\begin{array}{l}\text { Daily observed } \\
\text { methadone } \\
\text { (groups } 1 \text { and 2), } \\
\text { via RCT }\end{array}$ & $\begin{array}{l}\text { HIV and HBV } \\
\text { testing }\end{array}$ & $\begin{array}{l}\text { RCT comparing IPT } \\
\text { duration and } \\
\text { completion }\end{array}$ \\
\hline $\begin{array}{l}\text { Snyder } \\
(1999)\end{array}$ & $\begin{array}{l}1990 \\
- \\
1995\end{array}$ & $\begin{array}{l}\text { San } \\
\text { Francisco, } \\
\text { US }\end{array}$ & $\begin{array}{l}\text { Methadone } \\
\text { programme clients }\end{array}$ & $\begin{array}{l}\text { Screening and prevention: TST, } 6-12 \text { months DOPT }+ \text { methadone at OST } \\
\text { centre, in collaboration with TB programme. Referral to TB clinic for active TB } \\
\text { screening (see below) and IPT eligibility. Cross-service agreement on } \\
\text { admin./resource commitments. Community health worker facilitated at TB } \\
\text { clinic visits and followed up non-adherence. }\end{array}$ & $\begin{array}{l}\text { Existing OST } \\
\text { programme }\end{array}$ & $\begin{array}{l}\text { HIV testing, } \\
\text { counselling and } \\
\text { education }\end{array}$ & $\begin{array}{l}\text { Description of IPT } \\
\text { initiation, completion } \\
\text { and discontinuation }\end{array}$ \\
\hline $\begin{array}{l}\text { O'Connor } \\
(1999)\end{array}$ & $\begin{array}{l}1996- \\
1997\end{array}$ & $\begin{array}{l}\text { Connecticut } \\
\text {, US }\end{array}$ & OST clients & $\begin{array}{l}\text { Prevention: Liquid isoniazid added to methadone for IPT-eligible clients, daily } \\
\text { at OST centre; self-administered vitamin B6 (duration not specified). }\end{array}$ & $\begin{array}{l}\text { Existing OST } \\
\text { programme }\end{array}$ & - & $\begin{array}{l}\text { Description of IPT } \\
\text { completion }\end{array}$ \\
\hline Jansa (1998) & $\begin{array}{l}1988- \\
1992\end{array}$ & $\begin{array}{l}\text { Barcelona, } \\
\text { Spain }\end{array}$ & $\begin{array}{l}\text { PWID in } \\
\text { abstinence-based } \\
\text { drug treatment }\end{array}$ & $\begin{array}{l}\text { Prevention: } 6-12 \text { months daily DOPT at residential programme (eligibility: } \\
\text { TST+, no history of TB treatment). HIV-: } 6 \text { months; HIV+: } 9-12 \text { months. On } \\
\text { discharge, participants referred to outpatient TB clinic. IPT monitoring at } 1,3 \text {, } \\
6,9 \text { and } 12 \text { months. Attempted to trace clients not attending. }\end{array}$ & $\begin{array}{l}\text { Abstinence- } \\
\text { based; no OST }\end{array}$ & $\begin{array}{l}\text { HIV testing on } \\
\text { admission to } \\
\text { programme }\end{array}$ & $\begin{array}{l}\text { Comparison of TB } \\
\text { incidence by IPT } \\
\text { uptake and } \\
\text { completion }\end{array}$ \\
\hline \multicolumn{8}{|c|}{ Active TB screening and prevention at TB clinics, by referral from NSPs and OST centres } \\
\hline Rusen (1999) & 1996 & $\begin{array}{l}\text { Toronto, } \\
\text { Canada }\end{array}$ & $\begin{array}{l}\text { Recent-PWID } \\
\text { NSP clients }\end{array}$ & $\begin{array}{l}\text { Screening: TST+ NSP clients referred to TB clinic for active TB screening; } \\
\text { combined with incentivised TST at NSP (described above). No incentives. }\end{array}$ & None & - & $\begin{array}{l}\text { Description of referral } \\
\text { uptake }\end{array}$ \\
\hline
\end{tabular}




\begin{tabular}{|c|c|c|c|c|c|c|c|}
\hline Author (Year) & Dates & Location & Population & Intervention / model of care & Drug treatment & HIV \& HCV care & Evaluation method \\
\hline $\begin{array}{l}\text { Snyder } \\
(1999)\end{array}$ & $\begin{array}{l}1990 \\
- \\
1995\end{array}$ & $\begin{array}{l}\text { San } \\
\text { Francisco, } \\
\text { US }\end{array}$ & $\begin{array}{l}\text { Methadone } \\
\text { programme clients }\end{array}$ & $\begin{array}{l}\text { Screening: TST }+ \text { OST centre clients received facilitated referral to TB clinic for } \\
\text { active TB screening; coupled with TST at OST centre (described above). } \\
\text { Community health worker facilitated at TB clinic appointments. }\end{array}$ & $\begin{array}{l}\text { Existing OST } \\
\text { programme }\end{array}$ & $\begin{array}{l}\text { HIV testing, } \\
\text { counselling and } \\
\text { education }\end{array}$ & $\begin{array}{l}\text { Description of referral } \\
\text { uptake }\end{array}$ \\
\hline $\begin{array}{l}\text { Perlman } \\
(2003)\end{array}$ & $\begin{array}{l}1995- \\
2001\end{array}$ & $\begin{array}{l}\text { New York, } \\
\text { US }\end{array}$ & TST+ NSP clients & $\begin{array}{l}\text { Screening: TST+NSP clients received incentivised referral to hospital TB clinic } \\
\text { for active TB screening (X-ray). Incentives: } \$ 25 \text { cash + travel tokens for referral } \\
\text { uptake (coupled with TST (see Perlman } 1997 \text { \& Paone 1998)). }\end{array}$ & None & $\begin{array}{l}\text { HIV testing and } \\
\text { counselling onsite }\end{array}$ & $\begin{array}{l}\text { Comparison of } \\
\text { referral adherence } \\
\text { (pre/post) }\end{array}$ \\
\hline Ruutel (2011) & 2007 & $\begin{array}{l}\text { Johvi, } \\
\text { Estonia }\end{array}$ & $\begin{array}{l}\text { PWID in OST } \\
\text { programme }\end{array}$ & $\begin{array}{l}\text { Screening: Incentivised TST/IGRA at OST centre, then referral to TB clinic for } \\
\text { active TB screening. } 2 \text { intervention groups: (1) active referral: staff arranged } \\
\text { appointment, provided reminder, organised transport; (2) passive referral: client } \\
\text { organised appointment. }\end{array}$ & $\begin{array}{l}\text { Existing OST } \\
\text { programme }\end{array}$ & $\begin{array}{l}\text { HIV testing and } \\
\text { counselling }\end{array}$ & $\begin{array}{l}\text { Non-blinded RCT of } \\
\text { referral uptake }\end{array}$ \\
\hline \multicolumn{8}{|c|}{ 4. Pharmacy-based TB treatment, with referral for drug treatment } \\
\hline Juan (2006) & $\begin{array}{l}1999- \\
2002\end{array}$ & $\begin{array}{l}\text { Valencia, } \\
\text { Spain }\end{array}$ & $\begin{array}{l}\text { TB patients at } \\
\text { high risk of non- } \\
\text { adherence, } \\
\text { including PWID }\end{array}$ & $\begin{array}{l}\text { Treatment: DOTS at client's nearest pharmacy, via referral by hospital-based } \\
\text { social worker and TB specialist. Pharmacist facilitated contact with drug } \\
\text { treatment and social support services, provided non-adherence follow-up and } \\
\text { appointment reminders. Monthly meetings with all partners. }\end{array}$ & $\begin{array}{l}\text { Pharmacist } \\
\text { facilitated } \\
\text { contact with } \\
\text { drug treatment } \\
\text { services }\end{array}$ & None specified & $\begin{array}{l}\text { Comparison of DOTS } \\
\text { adherence with earlier } \\
\text { cohort (self-admin.) }\end{array}$ \\
\hline \multicolumn{8}{|c|}{ 5. TB service-led screening, prevention and treatment in collaboration with drug treatment and outreach services } \\
\hline Duarte (2011) & $\begin{array}{l}2005- \\
2007\end{array}$ & $\begin{array}{l}\text { Porto, } \\
\text { Portugal }\end{array}$ & $\begin{array}{l}\text { Ever-PWID } \\
\text { currently using } \\
\text { drugs }\end{array}$ & $\begin{array}{l}\text { Screening, prevention and treatment: Collaborative screening programme } \\
\text { involving TB clinic, OST centres, NSP/outreach teams, shelters, public health } \\
\text { department and hospital. Annual TST, IPT and DOTS at TB clinic. Partners } \\
\text { refer for TST and provide transport (if refused, arranged in community); offer } \\
\text { DOTS and co-located OST/DOTS if accepted. Across services, standardised TB } \\
\text { screening and adherence strategies; partners trained in TB treatment, screening, } \\
\text { counselling, negotiation and referral. }\end{array}$ & $\begin{array}{l}\text { OST via existing } \\
\text { OST programme } \\
\text { (outreach/centre) } \\
\text {, co-located with } \\
\text { DOTS if } \\
\text { accepted }\end{array}$ & $\begin{array}{l}\text { All partners offer } \\
\text { HIV, HBV and } \\
\text { HCV screening; } \\
\text { referral for } \\
\text { confirmation and } \\
\text { care }\end{array}$ & $\begin{array}{l}\text { Comparison of IPT } \\
\text { and DOTS non- } \\
\text { adherence and dis- } \\
\text { continuation } \\
\text { (pre/post) }\end{array}$ \\
\hline \multicolumn{8}{|c|}{ 6. TB treatment within drug treatment programmes } \\
\hline $\begin{array}{l}\text { Gourevitch } \\
\text { (1996) }\end{array}$ & $\begin{array}{l}1991 \\
-92\end{array}$ & $\begin{array}{l}\text { New York, } \\
\text { US }\end{array}$ & $\begin{array}{l}\text { Methadone } \\
\text { programme clients }\end{array}$ & $\begin{array}{l}\text { Treatment: 6-12 months DOTS (HIV+ } 12 \text { mo.) at co-located primary care and } \\
\text { substance use centre, initially inpatient. Also screening and prevention (see } \\
\text { model 3, above). }\end{array}$ & $\begin{array}{l}\text { Existing OST } \\
\text { programme }\end{array}$ & HIV testing onsite & $\begin{array}{l}\text { Description of DOTS } \\
\text { completion and } \\
\text { retention }\end{array}$ \\
\hline $\begin{array}{l}\text { Smirnoff } \\
(1998)\end{array}$ & 1998 & $\begin{array}{l}\text { New York, } \\
\text { US }\end{array}$ & $\begin{array}{l}\text { TB patients, } \\
\text { including OST } \\
\text { programme clients }\end{array}$ & $\begin{array}{l}\text { Treatment: DOTS and methadone at NGO-hospital OST centre with } \\
\text { multidisciplinary team. First } 2 \text { weeks inpatient then outpatient or home-based, } \\
\text { daily or } 2 x / \text { week. OST adjusted to account for interaction with DOTS. Non- } \\
\text { judgemental approach to adherence, focussing on completion. }\end{array}$ & $\begin{array}{l}\text { Existing OST } \\
\text { programme }\end{array}$ & - & $\begin{array}{l}\text { Description of DOTS } \\
\text { adherence and } \\
\text { completion (not } \\
\text { specific to PWUD) }\end{array}$ \\
\hline Marco (1998) & 1995 & $\begin{array}{l}\text { Barcelona, } \\
\text { Spain }\end{array}$ & $\begin{array}{l}\text { Prisoners with } \\
\text { active TB, } \\
\text { including PWID }\end{array}$ & $\begin{array}{l}\text { Treatment: DOTS and OST via prison infirmary and methadone centre, in } \\
\text { collaboration with city TB programme; weekly visits from TB nurse. On } \\
\text { release, referred to civilian OST centre; TB nurse facilitated access to financial } \\
\text { aid. Screening: TST; active TB screening. }\end{array}$ & $\begin{array}{l}\text { Existing OST } \\
\text { programme }\end{array}$ & $\begin{array}{l}\text { Voluntary HIV } \\
\text { testing }\end{array}$ & $\begin{array}{l}\text { Description of DOTS } \\
\text { adherence }^{c}\end{array}$ \\
\hline $\begin{array}{l}\text { Dhingra } \\
(2008)\end{array}$ & 2008 & $\begin{array}{l}\text { Chennai, } \\
\text { India }\end{array}$ & $\begin{array}{l}\text { PWUD TB } \\
\text { patients }\end{array}$ & $\begin{array}{l}\text { Treatment: DOTS + buprenorphine, food supplements and substance use } \\
\text { counselling at NGO clinic/detox. centre, under national TB programme. }\end{array}$ & $\begin{array}{l}\text { Buprenorphine at } \\
\text { detox. centre }\end{array}$ & None specified & $\begin{array}{l}\text { Description of DOTS } \\
\text { success and default }\end{array}$ \\
\hline
\end{tabular}

${ }^{\mathrm{a}}$ Some participants were receiving OST but this was unlinked to the intervention.

${ }^{\mathrm{b}}$ High-risk defined as positive or anergic TST result at initial assessment, or documented previously. Excluded those not tested for anergy within 3 months of negative TST result.

${ }^{\mathrm{c}}$ Adherence defined as not missing 3 consecutive days of DOTS. 


\section{Table 8: Uptake of tuberculin skin testing among PWID}

\begin{tabular}{|c|c|c|c|c|c|c|}
\hline Author & Intervention group & $\begin{array}{l}\text { No. } \\
\text { participants }\end{array}$ & TST placed & TST read & $\begin{array}{l}\text { Adjusted } \\
\text { odds ratio }\end{array}$ & Other predictors \\
\hline \multicolumn{7}{|c|}{ Model 1 (TB screening within PWID HIV risk studies) } \\
\hline Golub (2008) & Universally-offered un-incentivised TST & 2376 & $74 \%$ & - & NA & - \\
\hline Malotte (1998) & $\begin{array}{l}\text { No intervention } \\
\text { Education session only } \\
\$ 5 \text { cash on TST return } \\
\text { Education session }+\$ 5 \text { on TST return } \\
\$ 10 \text { cash on TST return } \\
\text { Education session }+\$ 10 \text { on TST return }\end{array}$ & $\begin{array}{c}100 \\
99 \\
204 \\
198 \\
200 \\
203\end{array}$ & - & $\begin{array}{l}33 \% \\
34 \% \\
86 \% \\
84 \% \\
93 \% \\
92 \%\end{array}$ & $\begin{array}{l}1 \\
1.1 \\
13.6^{* *} \\
12.9^{* *} \\
30.9^{* *} \\
26.0^{* *}\end{array}$ & $\begin{array}{l}\text { No current work; age } 41-50 \text {; no prior study } \\
\text { participation; intention to return }\end{array}$ \\
\hline Malotte (1999) & $\begin{array}{l}\text { No intervention } \\
\text { Education session only } \\
\$ 10 \text { fast-food/ travel tokens, on TST return } \\
\$ 10 \text { supermarket tokens on TST return } \\
\text { \$10 cash on TST return }\end{array}$ & $\begin{array}{l}215 \\
211 \\
218 \\
217 \\
217\end{array}$ & - & $\begin{array}{l}49 \% \\
47 \% \\
83 \% \\
86 \% \\
95 \%\end{array}$ & $\begin{array}{l}1 \\
0.9 \\
5.1^{* *} \\
6.4^{* *} \\
19.9^{* *}\end{array}$ & Age $>40$; ever-PWID (marginal) \\
\hline Lifson (1997) & $\begin{array}{lr}\text { Two-step TST, universally offered } & 1^{\text {st }} \text { test } \\
\text { Booster (after initial negative result) }\end{array}$ & & $83 \%$ & $\begin{array}{l}93 \% \\
90 \%\end{array}$ & NA & - \\
\hline $\begin{array}{l}\text { Swaminathan } \\
(2007)\end{array}$ & $\begin{array}{lr}\text { Two-step TST, universally offered: } & 1^{\text {st }} \text { test } \\
\text { Booster (after initial negative result) }\end{array}$ & $\begin{array}{l}806 \\
619\end{array}$ & - & $\begin{array}{l}98 \% \\
72 \%\end{array}$ & $\begin{array}{l}\text { NA } \\
\text { NA }\end{array}$ & $\begin{array}{l}\text { Not taking up booster testing: HIV+, } \\
\text { history of: IDU, living in shelter, } \\
\text { homelessness }\end{array}$ \\
\hline Lorvick (1999) & Incentivised TST ( $\$ 10$ on TST return), promoted but not actively offered & 223 & $92 \%$ & $87 \%$ & NA & - \\
\hline \multicolumn{7}{|c|}{ Model 3 (TB screening within NSP and drug treatment programmes) } \\
\hline Riley (2002) & Incentivised TST at NSP, promoted but not actively offered & 2372 & $13 \%$ & $84 \%$ & - & $\begin{array}{l}\text { TST placed: gender, }>3 \text { visits, fewer } \\
\text { exchanges/visit }(<11) \text { TST read: } \geq 15 \text { visits }\end{array}$ \\
\hline Perlman (1997) & Universally-offered incentivised TST at NSP & 493 & $97 \%$ & $91 \%$ & - & - \\
\hline Salomon (1999) & Universally-offered incentivised TST at NSP & 650 & $94 \%$ & $93 \%$ & - & TST read: know HIV-related TB is curable \\
\hline Fitzgerald (1999) & $\begin{array}{l}\text { Pre-intervention: TST only at NSP } \\
\text { Intervention: Incentivised TST at NSP }\end{array}$ & $\begin{array}{l}558 \\
549\end{array}$ & - & $\begin{array}{l}43 \% \\
78 \%\end{array}$ & - & - \\
\hline Rusen (1999) & Universally-offered incentivised TST at NSP & 167 & - & $93 \%$ & - & \\
\hline Snyder (1999) & Universally-offered TST at OST centre & 2151 & - & $99.6 \%$ & - & - \\
\hline \multicolumn{7}{|c|}{ Model 5 (TB-service led screening, in collaboration with drug treatment and harm reduction services) } \\
\hline Duarte (2011) & $\begin{array}{l}\text { Pre-intervention: passive case detection } \\
\text { Intervention: expanded, collaborative screening programme }\end{array}$ & - & - & $\begin{array}{l}42 \% \\
94 \%\end{array}$ & $21.8^{\mathrm{a}}$ & - \\
\hline
\end{tabular}

${ }^{a}$ Unadjusted; p not reported but 95\% confidence interval does not include zero (13.0-36.3)

${ }^{* *}$ Significant at $\mathrm{p}<0.01$. 


\section{Table 9: Uptake of active TB screening among PWID}

\begin{tabular}{|c|c|c|c|c|}
\hline Author & Intervention & No. participants & Uptake & Adjusted odds ratio \\
\hline \multicolumn{5}{|l|}{ Onsite } \\
\hline Lorvick (1999) & Onsite active TB screening via mobile $\mathrm{X}$-ray unit & 70 & $84 \%^{\mathrm{a}}$ & NA \\
\hline \multicolumn{5}{|l|}{ Off-site } \\
\hline Rusen (1999) & Referral from NSP to TB clinic for active TB screening & 44 & $43 \%$ & NA \\
\hline Snyder (1999) & Facilitated referral from OST centre to TB clinic for active TB screening & 487 & $96 \%$ & NA \\
\hline Perlman (2003) & $\begin{array}{l}\text { Referral from NSP to TB clinic for active TB screening } \\
\text { Pre-intervention: travel tokens only } \\
\text { Intervention: } \$ 25 \text { cash + travel tokens }\end{array}$ & $\begin{array}{c}119 \\
58\end{array}$ & $\begin{array}{l}14 \%^{\mathrm{a}, \mathrm{b}} \\
79 \% \%^{\mathrm{a}, \mathrm{b}}\end{array}$ & $\begin{array}{l}1 \\
22.9^{\mathrm{c}^{* *}}\end{array}$ \\
\hline Ruutel (2011) & Referral from OST centre to TB clinic for active TB screening & $\begin{array}{l}56 \\
56\end{array}$ & $\begin{array}{l}30 \% \\
57 \%\end{array}$ & $\begin{array}{l}1 \\
3.9^{\mathrm{d} * *}\end{array}$ \\
\hline
\end{tabular}

${ }^{a}$ Within 7 days of referral.

${ }^{\mathrm{b}}$ Ever attendance rates were higher: $34 \%$ before and $83 \%$ during intervention.

${ }^{c}$ Adjusted for having health insurance and unstable housing; both predicted ever attending for chest X-ray as did receipt of an incentive.

${ }^{\mathrm{d}}$ Adjusted for age, gender, education, employment status, IDU duration, history of prison, previous TB contacts, TST and HIV results.

Significant at $\mathrm{p}<0.01$. 


\section{Table 10: Initiation, adherence and completion of TB preventive therapy among PWID}

\begin{tabular}{|c|c|c|c|c|c|}
\hline \multirow{2}{*}{ Author } & \multirow{2}{*}{ Intervention } & \multirow{2}{*}{ No. participants } & \multicolumn{3}{|c|}{ \% (odds ratio, where reported) } \\
\hline & & & Initiation & Adherence & Completion \\
\hline \multicolumn{6}{|c|}{ Model 1 (TB prevention within PWID HIV risk studies) } \\
\hline Graham (1996) & 6 months+ IPT (DOPT/self-administered) & 125 & - & - & $56 \%$ \\
\hline Golub (2008) & 6 months IPT (DOPT/self-administered) & 2376 & $56 \%$ & - & $55 \%$ \\
\hline Lorvick (1999) & 6 months DOPT $+\$ 10$ cash incentive & 28 & $96 \%$ & $96 \%{ }^{\mathrm{a}}$ & $89 \%$ \\
\hline \multirow[t]{4}{*}{ Malotte (2001) } & 6-12 months DOPT & 224 & $90 \%$ & - & - \\
\hline & Outreach-delivered, no incentives & 55 & - & $12 \%$. & $4 \% \quad(1.0)^{\mathrm{c}}$ \\
\hline & DOPT at study site $+\$ 5$ & 55 & - & $69 \%$. & $60 \%(45.5)^{\mathrm{c}^{* *}}$ \\
\hline & Outreach-delivered DOPT $+\$ 5$ & 53 & - & $72 \%$. & $53 \%(29.7)^{\mathrm{c} * *}$ \\
\hline \multicolumn{6}{|c|}{ Model 2 (TB prevention for PWID at TB clinics) } \\
\hline \multirow[t]{3}{*}{ Chaisson (2001) } & 6 months DOPT at TB clinic & 99 & - & $77 \%{ }^{\mathrm{d}}$ & $80 \%^{\mathrm{d}}$ \\
\hline & 6 months self-administered IPT + peer counselling & 101 & & $6 \% \mathrm{~d}^{* *}$ & $78 \%$ (n.s.) ${ }^{\mathrm{d}}$ \\
\hline & Routine care: self-administered IPT only & 100 & & $10 \% \mathrm{~d}^{\mathrm{d}^{* *}}$ & $79 \%(\text { n.s. })^{d}$ \\
\hline \multicolumn{6}{|c|}{ Model 3 (TB prevention within drug treatment programmes) } \\
\hline Gourevitch (1996) & 6-12 months DOPT + methadone at co-located primary care/substance use centre & 125 & $82 \%$ & $88 \%{ }^{\mathrm{e}}$ & $48 \%{ }^{\mathrm{f}}$ \\
\hline Gourevitch (1999) & 12 months DOPT + methadone at co-located primary care/substance use centre & 431 & $34 \%$ & - & $49 \%$ \\
\hline Scholten (2003) & 6 months daily DOPT + methadone + vitamin B 6 at OST centre & 995 & $61 \%$ & $59 \%$ & $43 \%$ \\
\hline \multirow[t]{3}{*}{ Bakti (2002) } & Routine TB care; monthly IPT, no methadone & 39 & - & - & $13.1 \%^{\mathrm{g}}$ \\
\hline & Daily DOPT + methadone, no counselling & 35 & - & - & $77.1 \% \mathrm{~g}^{\mathrm{g}^{* *}}$ \\
\hline & Daily DOPT + methadone, substance use counselling & 37 & - & - & $59.5 \% \mathrm{~g}^{\mathrm{g}^{* *}}$ \\
\hline Snyder (1999) & 6-12 months daily DOPT + methadone at OST centre & 417 & $91 \%$ & - & $75 \%$ \\
\hline O’Connor (1999) & Combined liquid isoniazid + methadone at OST centre & 39 & - & - & $72 \%$ \\
\hline \multicolumn{6}{|c|}{ Model 5 (TB-service led prevention, in collaboration with drug treatment and harm reduction services) } \\
\hline Duarte (2011) & Pre-intervention & 26 & - & - & $58 \%$ \\
\hline & Intervention: annual TST screening at TB clinic; IPT non-mandatory & 96 & - & - & $44 \%$ \\
\hline
\end{tabular}

n.s. $=$ non-significant at $p<0.05$

${ }^{2}$ Adherence defined as number of directly-observed doses taken divided by expected no. directly-observed doses, over 6 months.

b Adherence defined as 'on-time' treatment, compared with treatment one day late/missed.

${ }^{\mathrm{c}}$ Adjusted for previous study participation and binge drinking during past 30 days.

${ }^{\mathrm{d}}$ Analysis compares to group receiving DOPT; adherence $=\%$ patients reporting adhering to $100 \%$ doses.

${ }^{\mathrm{e}}$ Adherence defined as at least 5 doses of IPT taken per week, in $80 \%$ of weeks observed.

${ }^{\mathrm{f}}$ IPT completion or retention was considerably higher at $84 \%$.

${ }^{\mathrm{g}}$ Completion defined as $\geq 80 \%$ (144/180) doses taken; analysis compares group receiving routine TB care with two other groups (combined).

${ }^{* * *}$ Significant at $\mathrm{p}<0.01$ compared with reference group. 


\section{Table 11: A summary of the key strengths and challenges of each model of TB and HIV-TB care for PWID}

\begin{tabular}{|c|c|}
\hline Model of care & Key strengths and challenges \\
\hline $\begin{array}{l}\text { Model 1: TB screening and } \\
\text { prevention within PWID HIV } \\
\text { risk studies }\end{array}$ & $\begin{array}{l}\text { - Provision of monetary and material incentives has achieved high uptake and completion of TB screening and prevention among PWID enrolled in HIV risk } \\
\text { studies } \\
\text { - Non-completion of TB screening among PWID has been linked to insecure housing, while motivational education - aimed at overcoming barriers to } \\
\text { returning for TST reading - has not been shown to increase completion } \\
\text { - Determining the most appropriate location and mode of TB prevention delivery for PWID requires an understanding of context-specific individual and } \\
\text { structural barriers to accessing care }\end{array}$ \\
\hline $\begin{array}{l}\text { Model 2: TB prevention for } \\
\text { PWID at TB clinics }\end{array}$ & $\begin{array}{l}\text { - Direct observation of TB prevention within TB services improved IPT adherence among PWID not in drug treatment } \\
\text { - There is some evidence that peer counselling and immediate (rather than deferred) also improved adherence }\end{array}$ \\
\hline $\begin{array}{l}\text { Model 3: TB screening and } \\
\text { prevention in NSP and drug } \\
\text { treatment } \\
\text { referral for active TB } \\
\text { screening }\end{array}$ & $\begin{array}{l}\text { - Actively offering PWID TB screening and prevention at NSPs and drug treatment programmes, respectively, has achieved good uptake and completion, } \\
\text { particularly when coupled with monetary and material incentives } \\
\text { - Incentivised, facilitated referral from NSP and drug treatment centres has improved active disease screening uptake in TB services } \\
\text { - Collaboration across services, with flexible appointment schedules, has helped to maximise PWID engagement in TB care } \\
\text { - Discontinuing methadone treatment, and experience or anticipation of side-effects, are key reasons for not adhering to or completing TB prevention. } \\
\text { Substance use counselling has shown no effect on completion of IPT. }\end{array}$ \\
\hline $\begin{array}{l}\text { Model 4: Pharmacy-based TB } \\
\text { treatment for PWID, with } \\
\text { referral for drug treatment }\end{array}$ & $\begin{array}{l}\text { - Pharmacy-based DOTS, with facilitated referral for OST and social care, has shown potential to improve TB treatment adherence, but further evidence of } \\
\text { this model's effectiveness is needed } \\
\text { - Increased coordination with OST programmes in this model could facilitate TB treatment uptake and adherence }\end{array}$ \\
\hline $\begin{array}{l}\text { Model 5: TB service-led } \\
\text { collaborative } \\
\text { prevention and treatment }\end{array}$ & $\begin{array}{l}\text { - A TB service-led collaborative intervention across existing health, drug treatment and outreach programmes, with a client-centred approach to care, has } \\
\text { improved TB screening and treatment uptake among PWID } \\
\text { - Engagement in TB prevention did not increase and remains a key challenge to TB care for PWID }\end{array}$ \\
\hline $\begin{array}{l}\text { Model 6: TB treatment within } \\
\text { drug dependency treatment } \\
\text { programmes }\end{array}$ & $\begin{array}{l}\text { - Small-scale integrated DOTS and OST programmes in diverse geographic and care settings (civilian and prison-based), with concurrent provision of } \\
\text { appropriate social care, have shown the potential to achieve good TB treatment adherence } \\
\text { - Such programmes remain vulnerable to insecure OST funding and availability }\end{array}$ \\
\hline HIV-TB integrated care & $\begin{array}{l}\text { - There is a dearth of documented case studies of HIV-TB models of care for PWID } \\
\text { - Integrated care centres have shown potential in Ukraine. Key strengths include multidisciplinary, harm reduction-based care; tailored case management; } \\
\text { patient-provider trust; and collaboration between government and NGOs } \\
\text { - Significant structural barriers include: inefficient staffing and a lack of training across specialties; poor OST availability; police interference; } \\
\text { insufficient funding; and poor infrastructure }\end{array}$ \\
\hline
\end{tabular}




\section{Table 12: Key recommendations based on this review}

- Effective integration of HIV, TB and drug dependency care requires collaboration across health, outreach and social care programmes, including prison health services, and should incorporate $\mathrm{HCV}$ care

- Integration is facilitated by taking a flexible, client-centred approach to care, with provision of appropriate incentives and social care

- Dedicated combined care centres have shown promise, but there is a need to document models of integrated HIV, TB and drug dependency service delivery in a variety of health-system contexts. Collaboration across existing services may offer an alternative approach to integration

- Structural barriers to integration - specifically restrictions on OST, policing, service organization and stigma associated with accessing HIV, TB and drug dependency care - need to be addressed across health, social and criminal justice sectors. Sustained advocacy for increased OST availability is vital

- Expanded surveillance, particularly of MDR-TB and co-infections with HIV and HCV, is needed to monitor and guide appropriate care for PWID

- Investigation of regimens with lower risk of toxicities and side-effects will be key to improving PWID's engagement in TB care

- Research on PWID's experiences of TB care would help to understand barriers to access, uptake and adherence, particularly regarding TB prevention

- Peer counselling may offer an effective way to improve PWID's awareness of and engagement in TB care and should be explored further 